\title{
1. SEISMIC STRATIGRAPHY AND STRUCTURE OF PRYDZ BAY, ANTARCTICA: IMPLICATIONS FROM LEG 119 DRILLING ${ }^{1}$
}

\author{
Alan Cooper, ${ }^{2}$ Howard Stagg, ${ }^{3}$ and Eric Geist ${ }^{2}$
}

\begin{abstract}
Prydz Bay is situated on the MacRobertson Land coast of East Antarctica at the seaward end of a 700-km-long transverse rift zone, the Lambert Rift. New and reprocessed seismic reflection data are combined with drilling results from five Leg 119 sites across Prydz Bay to study the regional stratigraphy and structure of the continental shelf and upper slope.

Severe seismic multiples hamper interpretations, yet seven acoustic units separated by unconformities can be distinguished regionally. Only four units (sedimentary) have been drilled. More than $5 \mathrm{~km}$ of well- to poorly-stratified units beneath the inner shelf fill the northeast-trending Prydz Bay basin, which is related to, but separated from, the Lambert Graben. Basinal units overlie metamorphic basement (unit PS.5) and are continental nonmarine deposits of possible late Paleozoic to early Mesozoic age (unit PS.4, Site 740) and Early Cretaceous and younger(?) age (unit PS.2B, Site 741). Seaward, the basin is flanked by a buried and intruded(?) basement ridge (units PS.5 and PS.6). Continuous to distorted reflections cover the ridge and dip seaward in a prograding unit (unit PS.2A) beneath the outer shelf. Glaciomarine rocks of late Eocene to early Oligocene age comprise the innermost part of the unit PS.2A (Sites 742 and 739) and Holocene glacial rocks the outermost (Site 743); ages of intermediate parts of the unit are unknown. A flatlying unit of chaotic to continuous reflectors directly beneath the seafloor covers most of the northeast shelf (unit PS.1, Sites 740, 741, 742, and 739), and is composed of compacted glacial diamictites of late Miocene and younger age.

We suspect that significant rifting and glacial events have caused acoustic disconformities beneath Prydz Bay. The principal rifting events began with earliest rifting of Gondwana in late Paleozoic time (units PS.5 to PS.4) and culminated with continental breakup in Early Cretaceous time (units PS.4 to PS.2B). The advent of East Antarctic glaciation in late Eocene to early Oligocene time (units PS.2B to PS.2A) and the grounding of ice sheets across the shelf in midand late-Cenozoic times (unit PS.1 to underlying units) created the principal glacial disconformities. The seaward-prograding glacial sequences beneath the outermost shelf record numerous post-early Oligocene glacial events and likely sea-level changes that can only be partially mapped with existing seismic and drilling data.
\end{abstract}

\section{INTRODUCTION}

During the austral summer of 1987-1988, a transect of five shallow holes was drilled across Prydz Bay on Ocean Drilling Program (ODP) Leg 119 (Fig. 1A), providing the first stratigraphic control for sedimentary units within the Lambert Graben-Prydz Bay rift zone. Previous seismic studies of the Lambert Graben (Masolov et al., 1981; Kurinin and Grikurov, 1982; Fedorov et al., 1982) and Prydz Bay (Stagg, 1985; Mizukoshi et al., 1988; Shelestov and Alyavdin, 1987) delineated the basic geometry and velocity structure of the underlying rift basins and sedimentary fill, but ages and stratal types were unknown. This paper uses the ODP drilling results to revise the seismic stratigraphy of Stagg (1985) and to define better the history of rifting and glaciation in the Prydz Bay region.

During Leg 119, seismic reflection, sonobuoy-seismic, and magnetic data were collected along several tracklines (lines 4 through 8; Barron, Larsen, et al., 1990) across the Prydz Bay shelf. These lines closely followed Stagg's (1985) line PB-21 (Fig. 1B), which was used to select the drill sites. We have combined the ODP tracklines into a single transect, herein named line ODP-119. The seismic data for lines ODP-119 and reprocessed PB-21 with our interpretation of line ODP-119 are shown in Figure 2 in the back pocket at the end of this volume (see also Appendix and BMR, 1989). The results of the ODP sonobuoyseismic surveys, which provide further acoustic stratigraphic con-

${ }^{1}$ Barron, J., Larsen, B., et al., 1991. Proc. ODP, Sci. Results, 119: College Station, TX (Ocean Drilling Program).

2 U.S. Geological Survey, 345 Middlefield Road, Menlo Park, CA 94025. U.S.A.

${ }^{3}$ Bureau of Mineral Resources, GPO Box 378, Canberra, Australia. trol and seismic-velocity data, are given by Cochrane and Cooper (this volume). Downhole logging measurements, made at two Prydz Bay sites (739 and 742) and used by us for acoustic-geologic correlations, are discussed more fully by Ollier et al. (this volume).

Our revised acoustic stratigraphy for Prydz Bay differs slightly from that of Stagg (1985) because (1) the seismic reflection data used by Stagg have been reprocessed to full 6-fold coverage, now giving better definition of acoustic units, (2) the drilling data provide geologic control for acoustic units, and (3) the new sonobuoy-seismic data give subsurface velocity data providing indirect indications of unconformities and burial history. The revised stratigraphy suggests an episodic rift history for Prydz Bay extending back possibly to late Paleozoic time. The acoustic geometry and ages of glacial strata imply a variable history of glacial deposition in the Prydz Bay region spanning at least the early Oligocene to the present. The present continental shelf edge beneath Prydz Bay has prograded at least 39 to $55 \mathrm{~km}$ seaward of the Paleogene location by deposition of thick glacial(?) sequences.

\section{REGIONAL GEOLOGY}

Geologic studies of the Prydz Bay region are extensive and are summarized by Ravich and Fedorov (1982) and Tingey (1982). The following is taken from those papers.

Prydz Bay lies at the oceanward end of a major graben (Lambert Graben), now occupied by the Lambert Glacier and Amery Ice Shelf, that extends landward for at least $700 \mathrm{~km}$. The Lambert Graben has bedrock depressions up to $5 \mathrm{~km}$ deep onshore and possibly 10- to 12-km-deep offshore in Prydz Bay, based on refraction and aeromagnetic data. Basement in the region is composed of Precambrian igneous and metamorphic rocks. Al- 


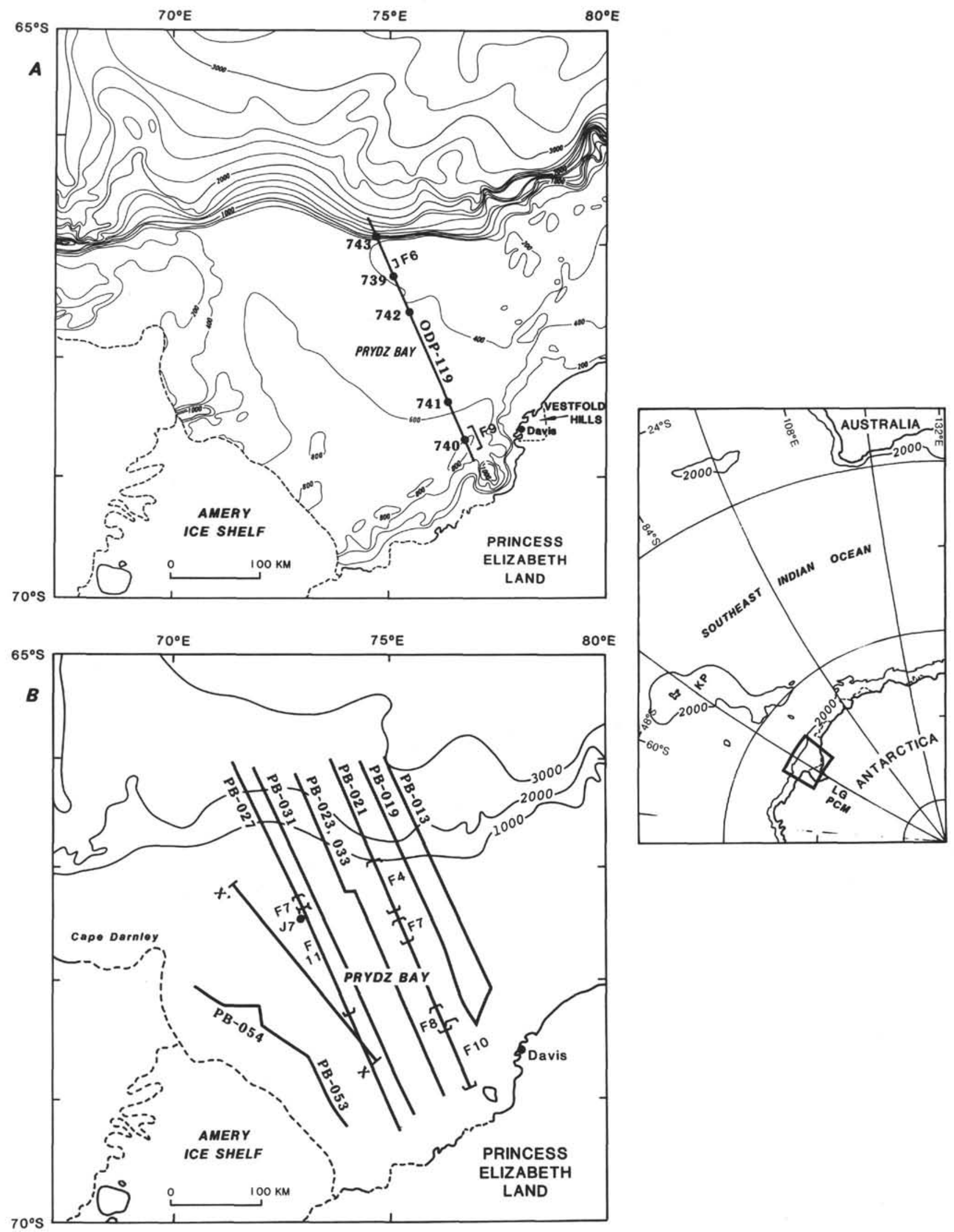

Figure 1. Index maps of Prydz Bay. A. Bathymetry (in meters) and locations of drill sites and line ODP-119. B. Locations of reprocessed seismic lines (PB, BMR, 1989), geophysical cross section (X-X' Shelestov and Alyavdin, 1987), and J7 sonobuoy location (Mizukoshi et al., 1988). KP = Kerguelen Plateau, PCM = Prince Charles Mountains, LG = Lambert Graben. 
kaline mafic igneous rocks of possible Cretaceous and Eocene ages occur sparsely along the southwest margin in the Prince Charles Mountains (Fig. 1C; Sheraton, 1983). Similar alkalic rocks of unknown age are found in the Vestfold Hills along the southeast side of Prydz Bay (Fig. 1A; Collerson and Sheraton, 1986).

Phanerozoic sedimentary rocks are known only from limited exposure of Permian age continental strata (with coal and redbeds) in the Beaver Lake area, $200 \mathrm{~km}$ southwest of Prydz Bay, and from thin outcrops of glacial rocks of Miocene and younger age in the Vestfold hills (Adamson and Pickard, 1986) and in the Prince Charles Mountains (Bardin, 1982) (Figs. 1A, 1C). The Lambert Glacier, Antarctica's largest outlet glacier, drains about $22 \%$ of East Antarctica via the Amery Ice Shelf and into Prydz Bay, and may have been a major source for Cenozoic glacial deposits in the offshore basins. Late Paleozoic, Mesozoic, and early Cenozoic strata were suspected within Prydz Bay from recycled palynomorphs found in seafloor core samples from the Shackleton Ice shelf area $\left(100^{\circ} \mathrm{E}\right.$; Truswell, 1982).

\section{ACOUSTIC STRATIGRAPHY}

\section{Seismic-Reflection Data}

Seismic reflection data from two sources were used for this study: (1) 6-fold seismic data recorded and reprocessed by the Bureau of Mineral Resources (BMR) and initially described by Stagg (1985) and (2) single-channel data recorded aboard the JOIDES Resolution during Leg 119. The Leg 119 seismic data were obtained using two 80 -in. ${ }^{3}$ water guns, a single-channel streamer, and a digital recording system (Barron, Larsen, et al., 1989). The data were filtered at 40 to $120 \mathrm{~Hz}$ to remove low-frequency $(5$ to $30 \mathrm{~Hz}$ ) reverberations caused by severe seafloor and interbed multiples. The BMR data (line PB-21) were filtered at 6 to $80 \mathrm{~Hz}$ and have a strong single reverberation $100 \mathrm{~ms}$ below and parallel to the seafloor reflector.

The difference in recording and processing (i.e., principally filtering) parameters of the ODP and BMR seismic reflection data yields profiles that appear quite different in places (compare lines ODP-119 and PB-21 in Fig. 2, back pocket). In general, the higher frequencies of ODP data give greater resolution of sedimentary structures (higher frequency band) but the large source and 6-fold stack of the BMR data give greater depth penetration and stronger seismic response. Although the acoustic signatures differ, major sedimentary and structural features can be traced across Prydz Bay in both data sets.

Difficulties were encountered in attenuating "geologic" noise in both the BMR and ODP seismic records. The noise results from several sources, including interbedded high- and low-velocity rocks close to the seafloor causing severe seafloor and internal multiples and highly variable seafloor reflections; iceberg gouges on the seafloor causing spurious reflection events across the seismic profiles; and localized channel and hummock deposits producing strong edge-diffractions through the data. The new drilling and downhole logging data have greatly helped to explain these and other acoustic signatures in the Stagg (1985) and ODP seismic data.

\section{Acoustic Units}

\section{Overview}

Stagg (1985) defined several acoustic units beneath the continental shelf (units PS.1 to PS.6) and continental slope (units PD.1 to PD.5). We use his model and reinterpret only those units on the shelf and uppermost slope where drilling was done. The general configuration of acoustic units remains the same, but we have modified several aspects of Stagg's (1985) stratigra- phy based on the new higher-resolution seismic and drilling data. The major changes are outlined as follows:

\begin{tabular}{|c|c|c|}
\hline \multicolumn{2}{|c|}{ Units } & \multirow[b]{2}{*}{ Comment } \\
\hline Stagg (1985) & This paper & \\
\hline PS.1 & PS.1 & Greater resolution of strata from drilling results. \\
\hline PS.2 & $\begin{array}{l}\text { PS.2A } \\
\text { PS.2B }\end{array}$ & $\begin{array}{l}\text { New distinction between mostly marine glacial } \\
\text { (PS.2A) and nonmarine preglacial (PS.2B) } \\
\text { strata. }\end{array}$ \\
\hline PS.3 & PS.3 & No change for this sedimentary unit. \\
\hline PS.4 & PS.4 & New lithologic control for strata from drilling. \\
\hline PS.5 & PS.5 & $\begin{array}{l}\text { Newly defined as acoustic (and metamorphic) } \\
\text { basement. }\end{array}$ \\
\hline PS.6 & $\begin{array}{l}\text { PS.5 } \\
\text { PS.6 }\end{array}$ & $\begin{array}{l}\text { New distinction between near-coast areas (PS.5) } \\
\text { and mid-shelf basement high (PS.6). }\end{array}$ \\
\hline
\end{tabular}

The general acoustic stratigraphy of Stagg (1985) (Fig. 3A) shows the steeply seaward-dipping reflections beneath the inner and outer parts of the Prydz Bay shelf and the nearly flat to gently undulating reflections beneath the central shelf. Drilling has confirmed that units PS. 1 to PS. 4 are sedimentary (unit PS. 3 was not sampled). Units PS.5 and PS.6 were not sampled, but are likely metamorphic and igneous rocks. The acoustic units are apparently separated by unconformities, but only the unconformity beneath unit PS.1 has been drilled.

\section{Acoustic Units-New Interpretations}

New geologic interpretations of acoustic units, especially PS.1, PS.2, and PS.4 (Fig. 3B), are based in part on drill core (Barron, Larsen, et al., 1989), sonobuoy-seismic (Cochrane and Cooper, this volume), downhole logging (Ollier et al., this volume), and magnetic-profile data. The newly interpreted ages and lithologies are summarized as follows:

\begin{tabular}{|c|c|c|c|}
\hline Units & Age & Lithology & Interpretation \\
\hline PS.1 & $\begin{array}{l}\text { Late Miocene } \\
\text { to Holocene }\end{array}$ & $\begin{array}{l}\text { Marine: diamictite } \\
\text { and diatom ooze }\end{array}$ & $\begin{array}{l}\text { Glacial tills, } \\
\text { topset beds } \\
\text { for PS.2A }\end{array}$ \\
\hline PS.2A & $\begin{array}{l}\text { late Eocene- } \\
\text { early Oligocene } \\
\text { to Holocene }\end{array}$ & $\begin{array}{l}\text { Marine: massive and } \\
\text { friable diamictite }\end{array}$ & $\begin{array}{l}\text { Glacial, pro- } \\
\text { grading } \\
\text { sequences }\end{array}$ \\
\hline PS.2B & $\begin{array}{l}\text { Early Cretaceous } \\
\text { and younger(?) }\end{array}$ & $\begin{array}{l}\text { Non-marine: sandstone, } \\
\text { siltstone, coal }\end{array}$ & $\begin{array}{l}\text { Fluviatile and } \\
\text { alluvial plain }\end{array}$ \\
\hline PS.3 & early Mesozoic(?) & $\begin{array}{l}\text { Non-marine } \\
\text { sediments(?) }\end{array}$ & $\begin{array}{l}\text { Alluvial } \\
\quad \text { plain(?) }\end{array}$ \\
\hline PS.4 & $\begin{array}{l}\text { late Paleozoic(?) } \\
\text { to early Meso- } \\
\text { zoic(?) }\end{array}$ & $\begin{array}{l}\text { Non-marine: silt- } \\
\text { stone and redbed } \\
\text { sandstone }\end{array}$ & $\begin{array}{l}\text { Preglacial, } \\
\text { fluvial basin }\end{array}$ \\
\hline PS.5 & PreCambrian(?) & Metamorphic rocks & Basement \\
\hline PS.6 & $\begin{array}{l}\text { PreCambrian(?) } \\
\text { and Mesozoic(?) }\end{array}$ & $\begin{array}{l}\text { Metamorphic and } \\
\text { intrusive rocks }\end{array}$ & $\begin{array}{l}\text { Intruded } \\
\text { basement }\end{array}$ \\
\hline
\end{tabular}

\section{Unit PS.1}

Unit PS.1 is the flat-lying unit directly below the seafloor that covers most of the northeast part of the shelf (Fig. 2, back pocket; Fig. 4). Chaotic, ineoherent, and some continuous reflections characterize the unit. Beneath the outer shelf (seaward of Site 739), more continuous, flat-lying reflections are observed, and these are apparently topset strata for the seaward-prograding reflectors of unit PS.2A (see below). Unit PS.1 varies in thickness from a few meters beneath the inner and western parts of Prydz Bay to nearly $250 \mathrm{~m}$ beneath the outer and eastern parts of the bay. 
$\boldsymbol{A}$
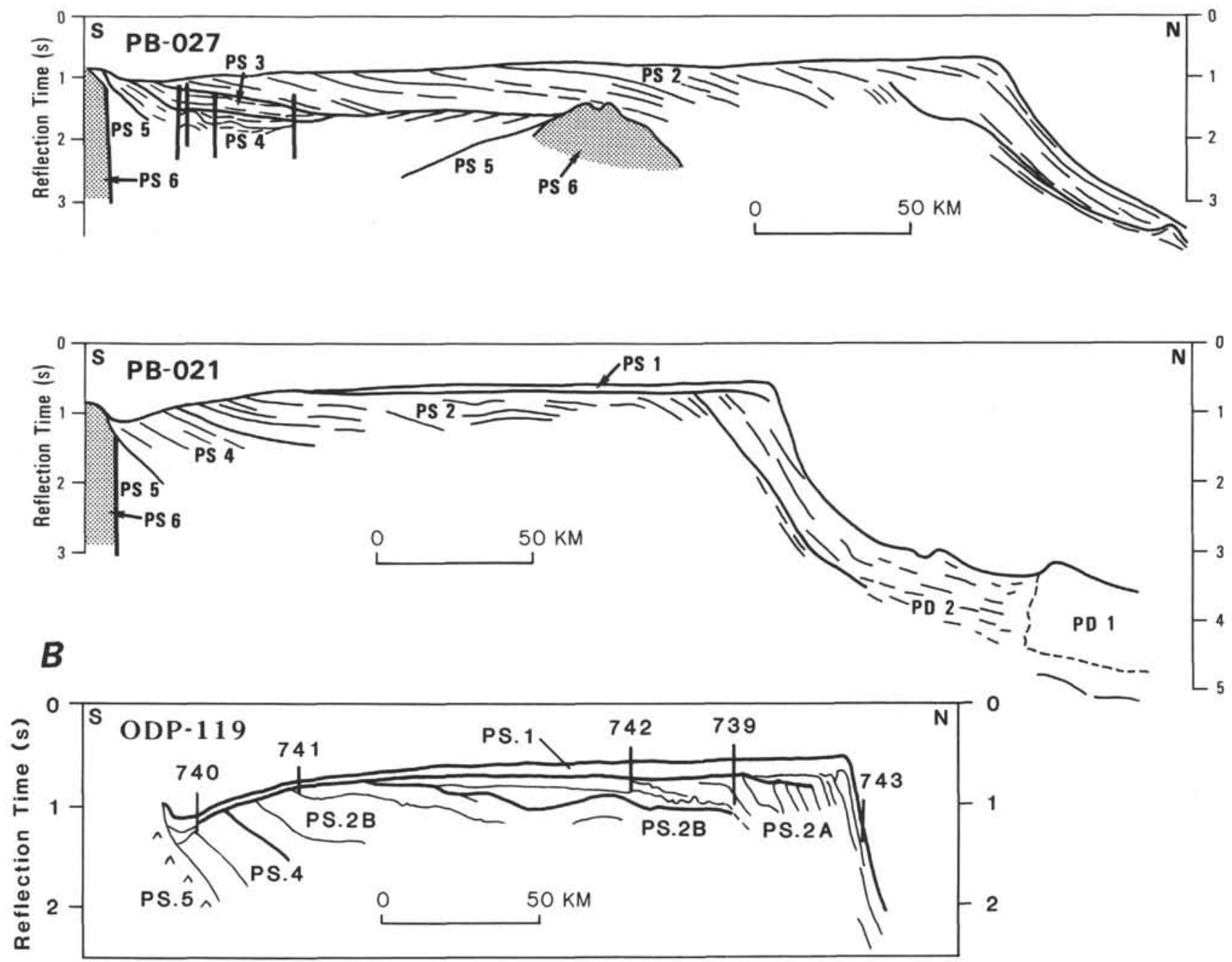

Figure 3. Line drawings of select seismic lines across Prydz Bay showing acoustic units. A. Units of Stagg (1985). B. Units defined by this study. See Figure 1 for location of seismic lines.

Unit PS.1 was encountered at all Prydz Bay drill sites, and is composed of thin diatomaceous oozes (Holocene), up to a few meters thick at the seafloor (thicker near shore in local troughs), overlying glacial deposits composed of gravels and highly compacted to massive diamictite. Ages for unit PS.1 range from late Miocene (Site 739) to Holocene (all sites). The unit is marine and of glacial and interglacial origins.

The highly varied acoustic character of unit PS.1 is best explained by highly variable velocities ( 1.8 to $2.6 \mathrm{~km} / \mathrm{s})$ measured by downhole logging at Sites 739 and 742 . Synthetic-seismic traces computed using ODP water-gun signatures and downhole logs (Fig. 5) clearly show the complex waveforms that are the likely explanation for the chaotic acoustic character of unit PS.1. Two strong reflectors occur within unit PS.1 near and between Sites 739 and 742 at subsurface depths of about 120 and 170 meters below seafloor (mbsf; Fig. 5). Downhole logs show that abrupt velocity increases ( 2.0 to $2.6 \mathrm{~km} / \mathrm{s}$ ) and decreases ( 2.6 to $1.9 \mathrm{~km} / \mathrm{s}$ ) occur at equivalent depths and cause the reflections (Fig. 5). The abrupt velocity changes mark the top and bottom of a layer that was overcompacted probably by glacial loading (Barron, Larsen, et al., 1989; Solheim et al., chapter 9, this vol- ume). The base of the overcompacted zone corresponds to the unconformity at the top of the late Eocene-early Oligocene diamictites (unit PS.2A) at Sites 739 and 742.

\section{Unit PS.2}

Unit PS.2 was defined by Stagg (1985) as being composed of well-layered, semicontinuous, and discontinuous reflectors that dip seaward beneath the Prydz Bay shelf. We separate unit PS.2 into two distinctly different lithologic (and acoustic) units based on drilling: (1) unit PS.2A lies principally beneath the outer shelf and is composed of marine glacial strata of late Eoceneearly Oligocene and younger ages (Sites 739, 742, and 743) and (2) unit PS.2B contains nonmarine continental strata of Early Cretaceous and younger(?) ages (Site 741).

The discontinuity, or unconformity, between units PS.2A and PS.2B separates glacial and preglacial rocks, but this horizon is difficult to identify in seismic reflection profiles and was not drilled. The apparent discontinuity is more easily seen in the eastern than in the western part of Prydz Bay, because of greater contrast in reflection amplitudes and dips (Fig. 2, back pocket). 
$S$

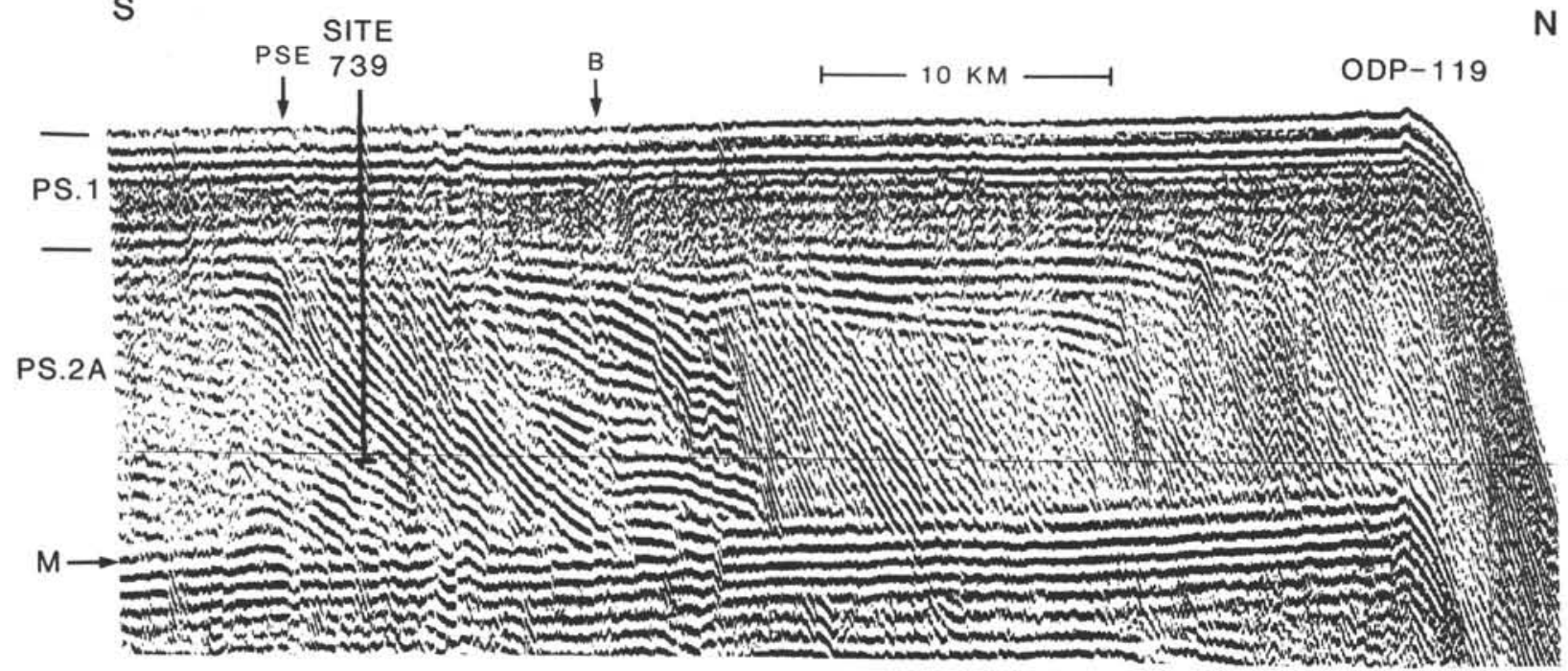

$\mathbf{N}$

\section{PB-21}

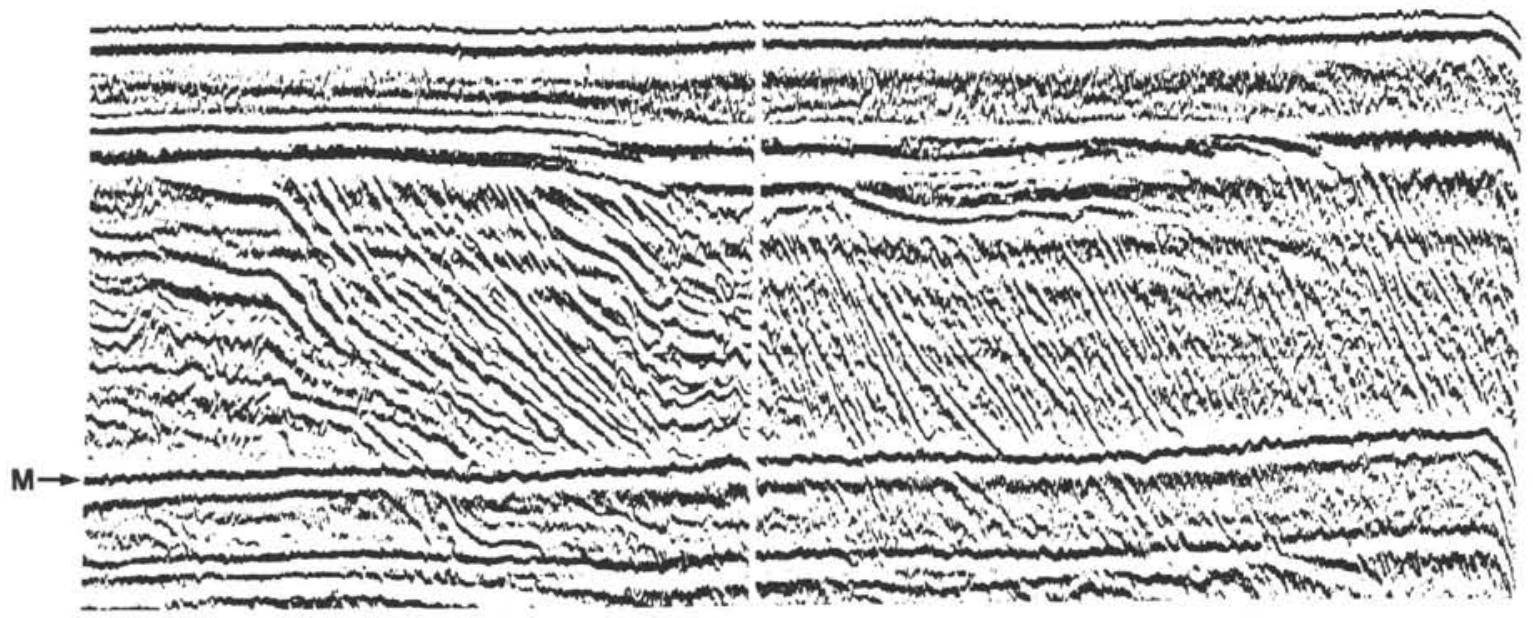

Figure 4. Seismic reflection profiles along lines PB-21 (bottom) and ODP-119 (top) showing examples of dipping glacial rocks beneath outer Prydz Bay shelf. Differences between the two lines illustrate the effect of different recording and processing parameters, as the lines are nearly coincident. Line ODP-119 does not have automatic gain control. See Figure 1 for location. PSE = paleo-shelf edge, $\mathrm{B}=$ reference point, $\mathrm{M}=$ multiple.

\section{Unit PS.2A}

The gently dipping (topset) and steeply dipping (foreset) reflections beneath the middle and outer shelf, respectively, comprise the thick prograding continental-margin unit PS.2A. Where sampled, unit PS.2A is composed of marine glacial rocks. The unit can be identified on all seismic reflection transects of the Prydz Bay shelf. An abrupt change in reflector dips within unit PS.2A occurs about 39 to $55 \mathrm{~km}$ landward of the shelf break. Site 739 was drilled directly seaward of this dip change (paleoshelf edge, or PSE, Fig. 4). Seismic profiles across the outer shelf show other notable dip changes within PS.2A at distinct boundaries between depositional packages, or sequences (Fig. 6; Fig. 2, back pocket). The lateral geometry and extent of the sequences within unit PS.2A is unknown because seismic tielines were not recorded. Short seismic cross-lines recorded across each drill site indicate that the strike of dipping strata is generally parallel to the present shelf edge (i.e., nearly perpendicular to lines ODP-119 and PB-21).

Drill cores at Sites 739 and 742 reveal that the entire drilled section within unit PS.2A is composed of massive to stratified diamictites with little internal structure (Barron, Larsen, et al.,
1989). The downhole logging measurements at Site 739, however, show a distinct change from highly variable velocities in the shallow steep-dipping strata (i.e., foreset beds) to a smooth velocity gradient, with a few lower velocity troughs, in the underlying shallow-dipping strata (i.e., in older buried topset(?) beds; Fig. 5). Seismic reflection profiles (Fig. 2, back pocket) also show greater variability in reflector amplitude and continuity for the steeply dipping strata than for the underlying shallow dipping strata, compatible with variability of downhole measurements. Notably, the continuous reflections with shallow dip at Site 739 (i.e., at depths greater than 340 mbsf) are caused by 1- to 3-m-thick lower velocity layers probably composed of uncemented sand. (However, rocks were not recovered from the low-velocity layers; Barron, Larsen, et al., 1989.)

Beneath the outermost shelf, we draw the boundary between units PS.2A and overlying PS.1 along the angular unconformity that can be traced about $24 \mathrm{~km}$ seaward of Site 739 , where the unconformity disappears (Fig. 2, back pocket; Figs. 3 and 4). By this definition, units PS.2A and PS.1 are part of the same sequence(s) beneath the outermost $10 \mathrm{~km}$ of the shelf, with the possible exception of the uppermost 80 milliseconds (ms) $(80 \mathrm{~m})$, where reflections are obscured by the bubble pulse. 

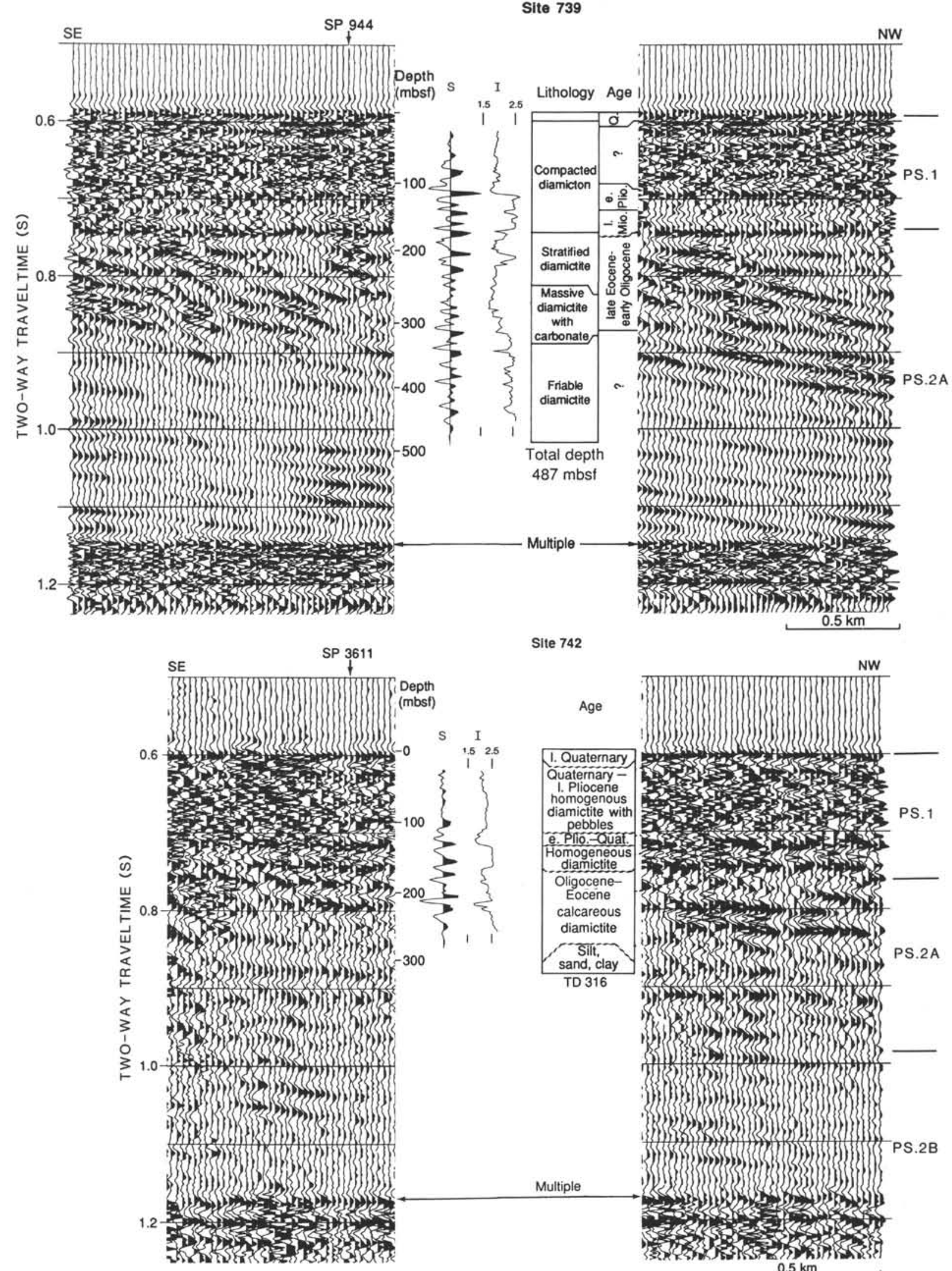

Site 742

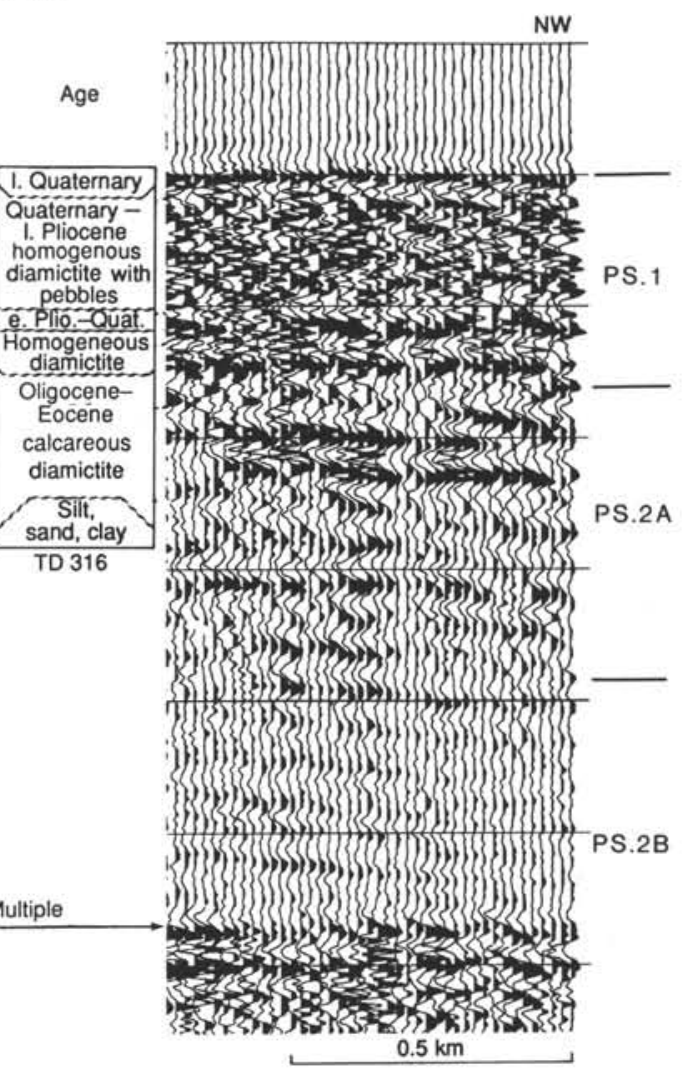

Figure 5. Comparison of seismic reflection profile, drill core, and downhole seismic data at Sites 739 and 742 (modified from Barron, Larsen, et al., 1989). The synthetic seismic traces were computed using the impedance (i.e., velocity only) curves and the direct-arrival waveform of the Leg 119 water guns. All seismic data are filtered at 40 to $120 \mathrm{~Hz}$. The only reflectors that can be reliably correlated between the two drill sites in the seismic profile and downhole impedance data occur at the top and bottom of an overconsolidated high-velocity layer at 115 to $175 \mathrm{mbsf}$ at Site 739 and at 125 to $175 \mathrm{mbsf}$ at Site 742. 
$0.5-S$

N

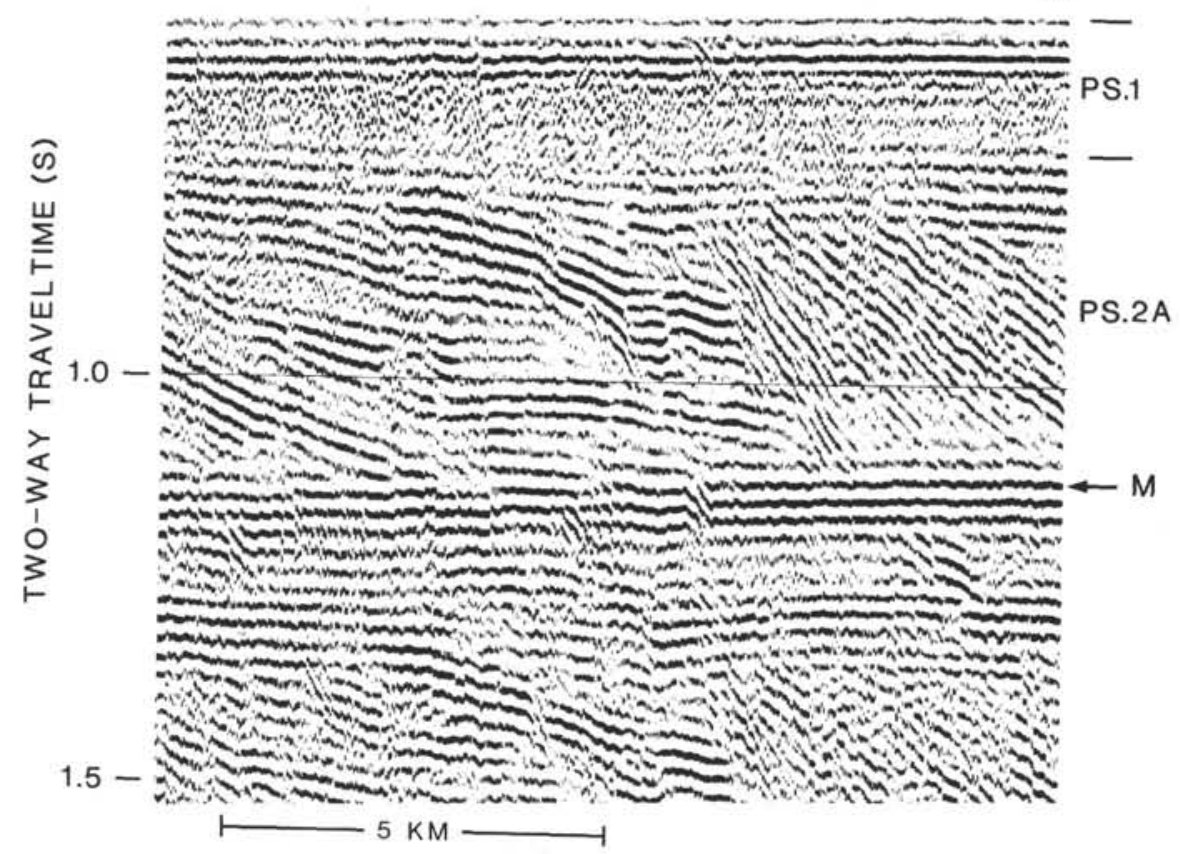

Figure 6. Line ODP-119 segment showing the chaotic and layered reflections of unit PS.1 that unconformably overlie the seaward-dipping reflections of unit PS.2A. The boundary between the two glacial units is not sharply defined. Reflections cannot be reliably traced below the strong seafloor multiple (M). See Figure 1 for location.

Where present, the angular unconformity separating units PS.2A and PS.1 is more clearly seen in line ODP-119 than line PB-21 (Fig. 2, back pocket) because low-frequency noise has been filtered from line ODP-119. The clarity of this and other unconformities in the seismic data is, however, highly sensitive to the choice of filtering and automatic gain control used for data display, especially for glacial rocks with highly variable velocities.

Downhole logging and ages from drill cores at Sites 739 and 742 suggest that the unconformity lies at the base of a high-velocity layer within unit PS.1 (Fig. 5). Seaward of Site 739, however, the large reflections marking the top and bottom of the high-velocity layer become less distinct, and identification of the unconformity (and base of unit PS.1) is based on angular divergence of reflections.

Reflections within unit PS.2A are commonly continuous to semicontinuous and relatively undeformed, but in a few midshelf low-dip areas, highly distorted or deformed reflections occur in distinct units that have irregular tops and bottoms (Figs. 7A and 7B). The distorted units are more readily recognized beneath western Prydz Bay where seismically dispersive unit PS.1 is thin or missing. During drilling at Site 742 we sampled the uppermost part of the distorted unit (Fig. 7B). Here, a distinct lithologic change was seen from glacial diamictites in the overlying, evenly layered unit to deformed sands and carbonaceous shales also of likely glacial origin in the distorted unit. At this location, we place the unconformity between glacial and preglacial rocks at the base of the distorted unit. On line PB-27 (Fig. 7A), at least two distinct distorted units are interbedded between layered sections, and all lie within the presumed glacial unit PS.2A.

Unit PS.2A thins landward across Prydz Bay probably extending to within 100 to $130 \mathrm{~km}$ of the coast where it is truncated near the seafloor (Fig. 2, back pocket). Reflection dips across the midshelf areas are small and individual reflections are difficult to trace, especially on line PB-21. A buried midshelf swale along line ODP-119 is filled with discontinuous and dis- torted reflections similar to those sampled at the bottom of Site 742 (Fig. 2, back pocket). We include the distorted unit, which fills the swale, in unit PS.2A (i.e., glacial) based on reflection character and on disconformity of reflections with underlying horizons. However, the unit could be part of PS.2B (or another unit) because a disconformity also occurs at the top of the unit. Although this unit is observed on lines PB-19 and PB-13 (east of line ODP-119; Fig. 1B), it is not apparent on seismic profiles to the west of line ODP-119.

\section{Unit PS. $2 B$}

Unit PS.2B can be traced in seismic profiles across most of Prydz Bay from near shore, where the unit dips steeply and is eroded at the seafloor, to within about $30 \mathrm{~km}$ of the continental shelf break, where the unit drops steeply into the seafloor multiple (Fig. 2, back pocket). The unit is characterized, in places, by either mostly discontinuous or continuous reflections: (1) discontinuous reflections characterize the upper and inner shelf parts of unit PS.2B and (2) continuous reflections occur in the lower and outer shelf parts of unit PS.2B

Only the upper, inner shelf part of unit PS.2B has been drilled (Site 741, Fig. 8). Rocks recovered include Early Cretaceous nonmarine sandstone and fine-grained silt that was relatively rich in carbonized plant material (Barron, Larsen, et al., 1989; Turner and Padley, this volume). Scattered thin beds of highly cemented and high-velocity sandstone $(3.2$ to $4.8 \mathrm{~km} / \mathrm{s})$ were recovered. Hole 741A was not logged, but physical property measurements showed significant decreases in bulk density caused by local increases in carbon content of the rocks (Barron, Larsen, et al., 1989). We suspect that lateral variations in carbonaceous material (i.e., variations in bulk density) and thickness variations of the high-velocity sandstones result in poor reflection continuity in the nonmarine sedimentary rocks.

Laterally, reflections within unit PS.2B have greater continuity from a point below the midshelf swale seaward to near Site 739 (line ODP-119, Fig. 2, back pocket). The greater continuity 

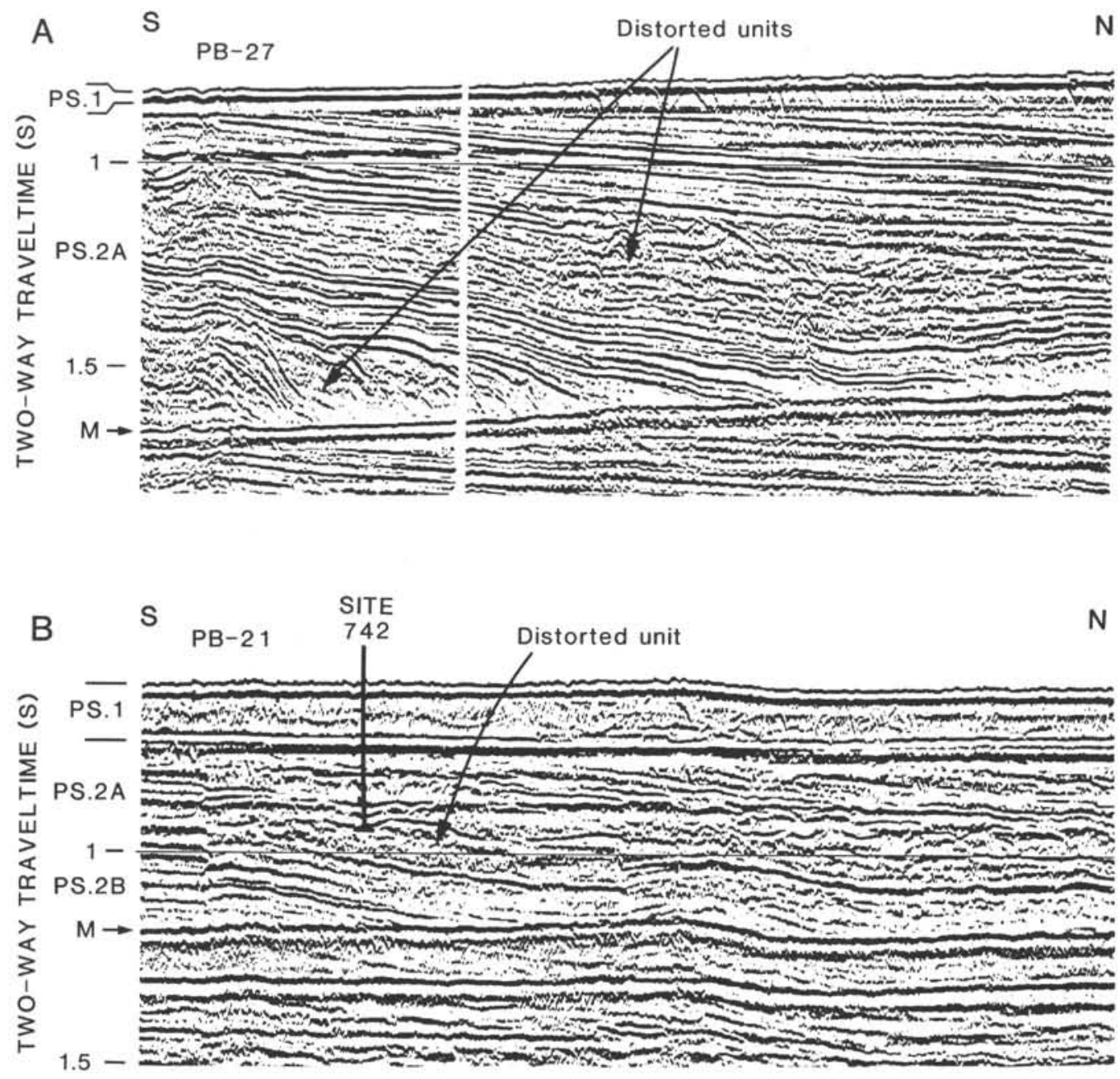

Figure 7. Seismic profiles showing distorted reflections interbedded between layered strata within glacial unit PS.2A. A. Line PB-27 segment showing interbedded and restricted nature of the distorted reflectors. B. Line PB21 segment showing the poorly delineated, but distorted unit that was sampled in the lowermost core at Site 742 as deformed, laminated glacial silts and sands. See Figure 1 for location. $\mathbf{M}=$ multiple.

may indicate a change from terrestrial to shallow marine deposition along the outer paleo-shelf.

\section{Unit PS.3}

Unit PS. 3 exhibits most of the same acoustic characteristics as unit PS.2B, and is identified by Stagg (1985) from acoustic discordance with overlying units. The unit does not occur on line ODP-119 and was not drilled.

\section{Unit PS.4}

Unit PS.4 is seen in seismic profiles only beneath the inner shelf, as a poorly to well-layered unit of mostly low-amplitude reflectors that dip seaward into the Prydz Bay basin and are lost in the seafloor multiple (Fig. 2, back pocket; Figs. 9 and 10). Unit PS.4 again appears at the flank of a midshelf basement high where the unit dips landward, is eroded, and is overlain by unit PS.2B (Fig. 11). Unit PS.4 cannot be seen on the seaward flank of the midshelf basement high; if present, unit PS. 4 is hidden by the seafloor multiple reflection. At Site 740 , a nonmarine unit of nonfossiliferous redbed sandstones and siltstones with coaly fragments was recovered from the middle of unit PS.4 (Barron, Larsen, et al., 1989).
An angular unconformity separates unit PS.4 and the overlying unit PS.2B in the western part of Prydz Bay along line PB-27 (Fig. 11). The unconformity becomes nearly conformable with unit PS.2B in eastern Prydz Bay along line ODP-119 (Fig. 10). Another angular unconformity separates unit PS.4 from the thin veneer of glacial rocks of unit PS.1 and occurs directly below the seafloor in the southern, and deepest, part of Prydz Bay. The ages of these unconformities are unknown.

\section{Units PS.5 and PS.6}

Unit PS.5 is an acoustically opaque unit (i.e., without internal structure) that lies beneath unit PS.4. The top of the unit is a high-amplitude continuous reflector that is mostly without relief (Figs. 10 and 11). We include the irregular, hyperbolic reflection surface adjacent to the southern coastline as part of unit PS.5, although Stagg (1985) called this PS.6 (see the following discussion). Unit PS.5 was not drilled, but from onshore geology we believe it is composed of Precambrian basement rocks.

Unit PS.6 occurs, according to this work, only along the axis of a basement high that lies beneath the central part of Prydz Bay (Figs. 12 and 13D). The unit is characterized by a highly irregular upper surface with diffractions and a high-amplitude 
$\mathrm{S}$

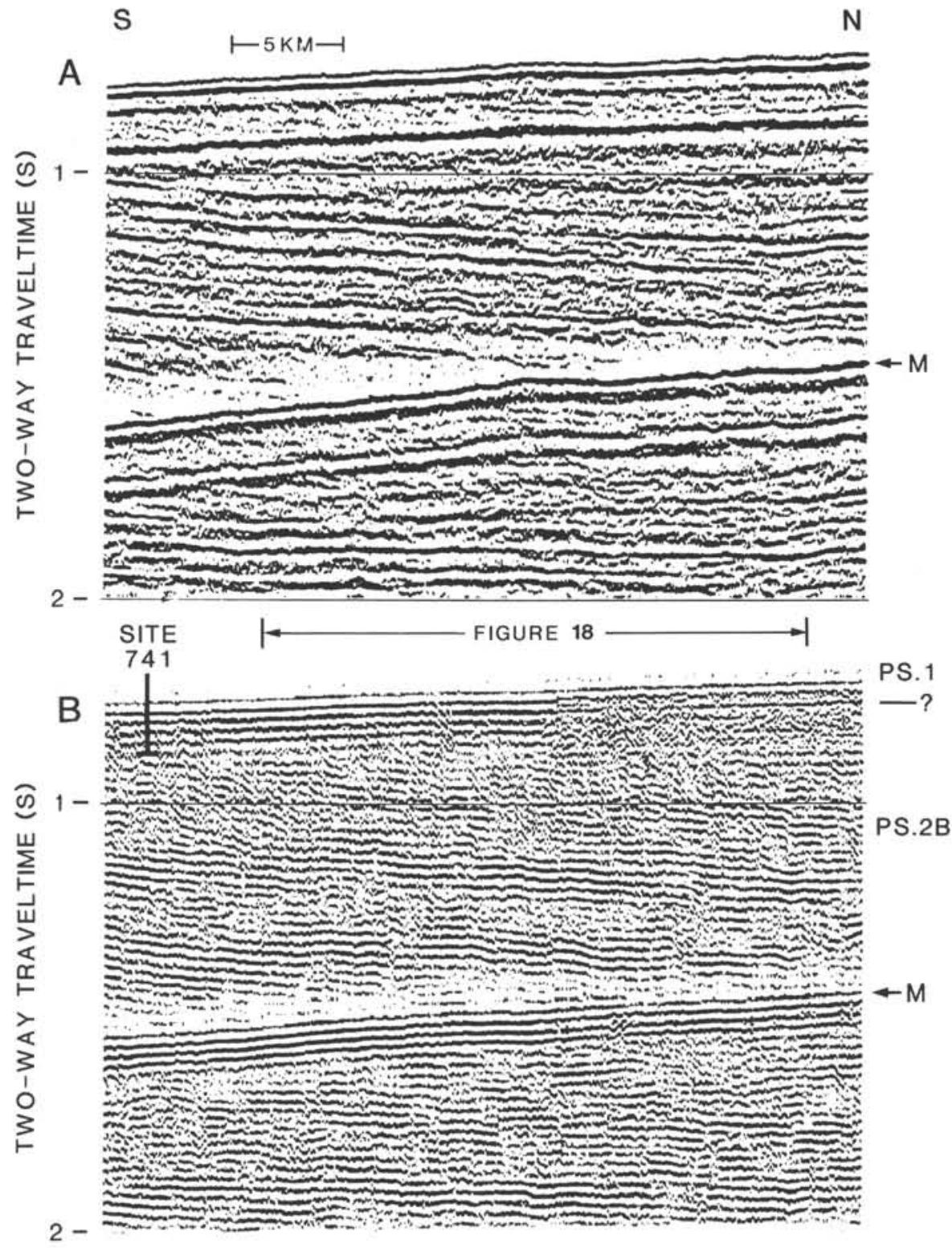

Figure 8. Seismic profiles showing examples of unit PS.2B near Site 741 where Early Cretaceous age nonmarine carbonaceous silts and sandstone were recovered. A. Line PB-21. B. Line ODP119. See Figure 1 for location. $M=$ multiple.

magnetic anomaly (Figs. 11 and 12). Unit PS.6 is best seen along line PB-27 (Fig. 11), although only regional magneticanomaly data are available here (Fig. 12A; Shelestov and Alyavdin, 1987). A magnetic high is observed along the eastward projection of the basement high on line ODP-119 (Fig. 12B), but the basement structure is hidden by the seafloor multiple on line ODP-119. We interpret unit PS.6 as intrusive rocks that are younger than the Precambrian basement they intrude and older than the sedimentary strata of unit PS.2B that bury the intrusives.

Our revised interpretation that, near the coast, unit PS.5 is metamorphic basement, and not sedimentary, is based on sonobuoy-seismic interpretations (Cochrane and Cooper, this volume) and magnetic profiles (Fig. 12B). Sonobuoy data show that unit PS. 5 has a velocity of about $5.7 \mathrm{~km} / \mathrm{s}$ with small internal velocity gradients. Both characteristics are consistent with metamorphic basement rocks. Additionally, a magnetic anom- aly is not recorded approaching the coast along line ODP-119, where unit PS.5 is rising steeply and Stagg (1985) shows a vertical fault contact between units PS.5 and PS.6. We suspect that, here, Stagg's units PS.5 and PS.6 are composed of equivalent rocks (i.e., our unit PS.5), and that basement relief results from possible basement faulting and erosion.

\section{Areal Distribution of Acoustic Units}

Maps showing the thickness and distribution of selected acoustic units beneath Prydz Bay have been compiled using the seismic data of Stagg (1985) after reprocessing, and new drilling results (Figs. 13B and 13C). Further maps showing the distribution of unsampled acoustic units beneath the continental slope and adjacent areas are given by Stagg (1985).

A striking feature of the profiles and maps (Figs. 12, 13B, and $13 \mathrm{C}$ ) is that more than two-thirds of Prydz Bay is covered by thick (i.e., greater than $50 \mathrm{~m}$ ) glacigenic rocks of either units 


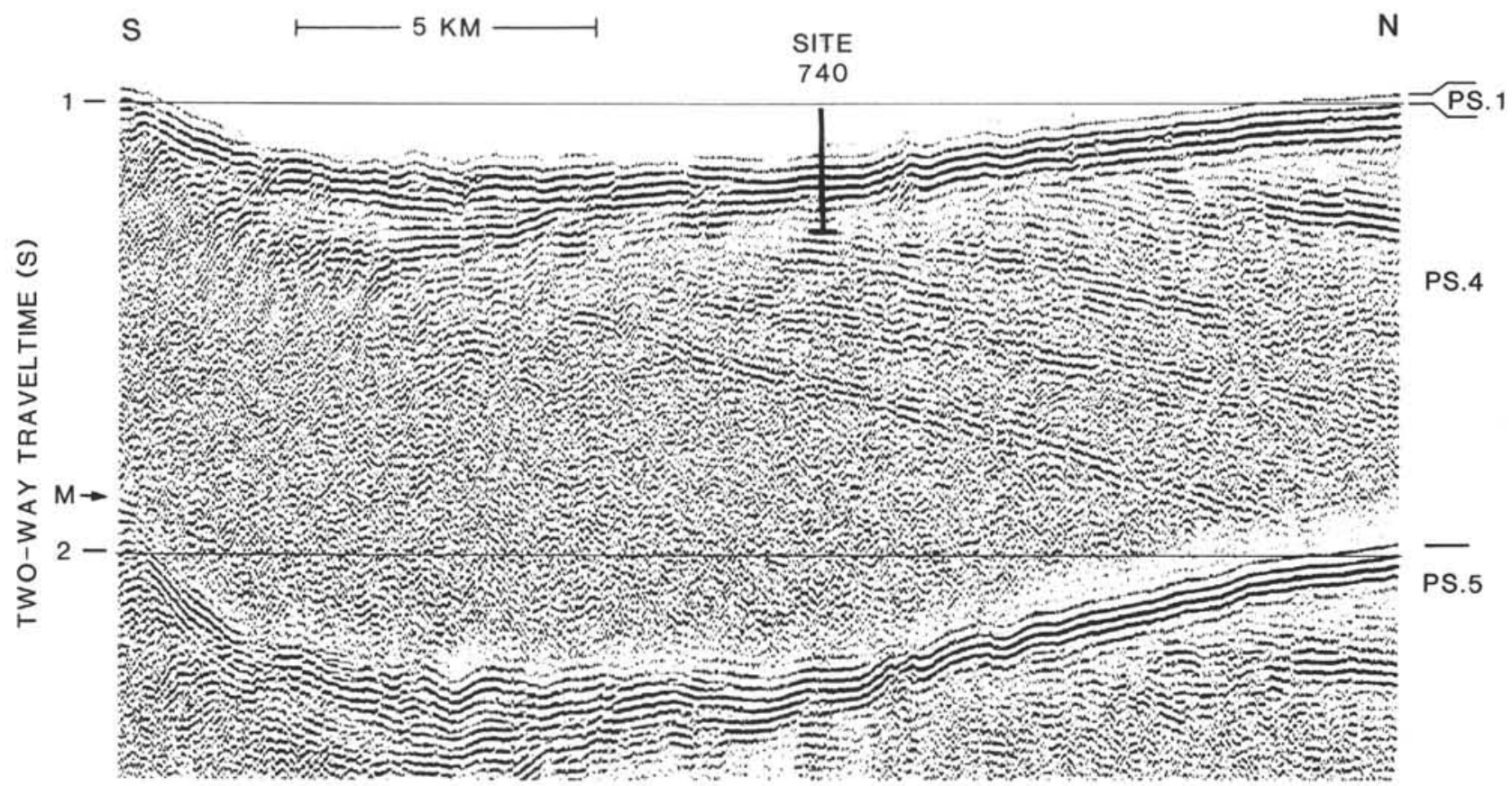

Figure 9. Line ODP-119 segment showing example of unit PS.4 near Site 740 where a continental redbed section of fluvial silts and sands of unknown age was recovered from the dipping reflections. See Figure 1 for location. $\mathrm{M}=$ multiple.

S

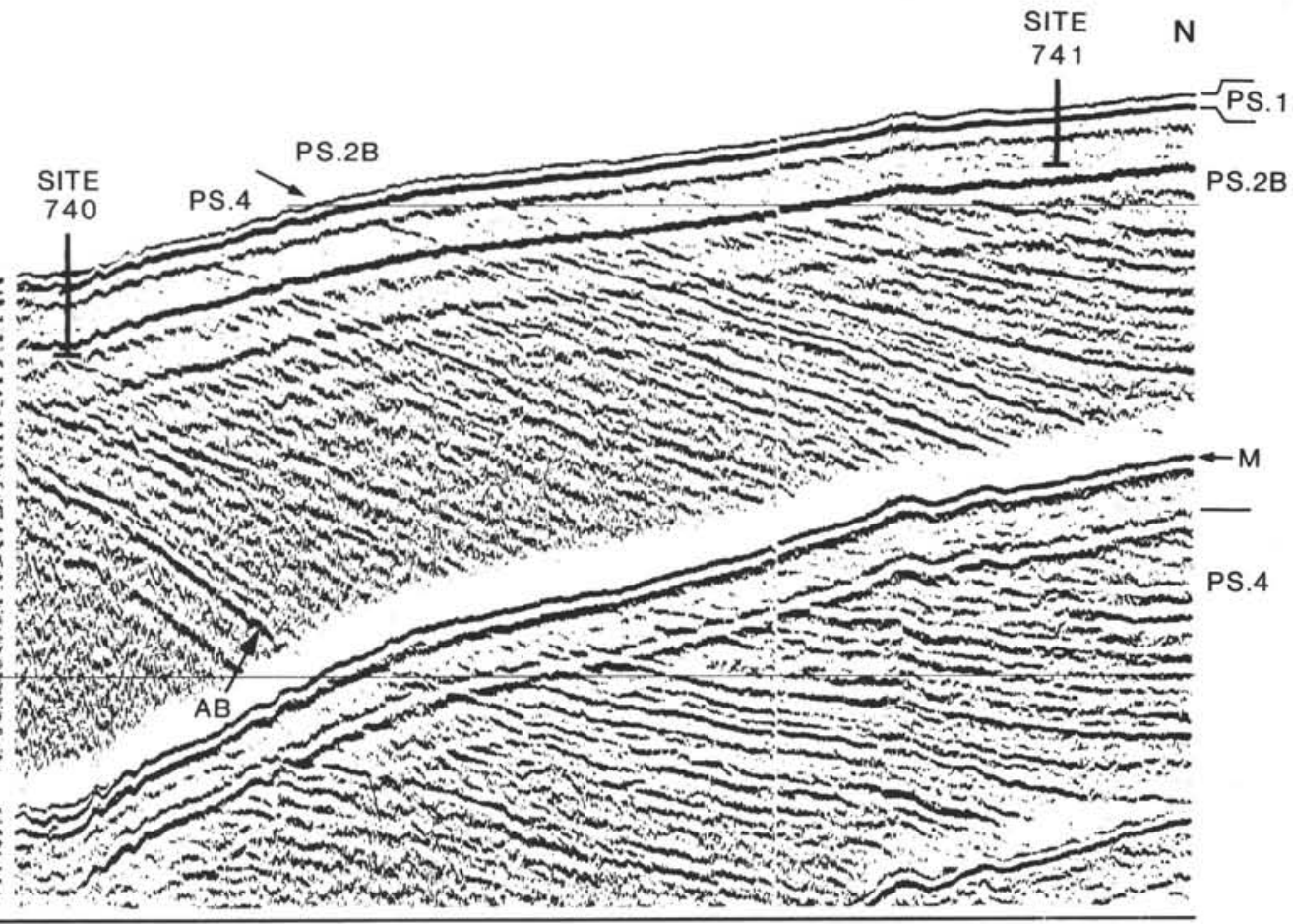

Figure 10. Line PB-21 segment showing the disconformity between units PS.4 and PS.2B between Sites 740 and 741 . The strong smooth reflection at the base of the layered section is acoustic basement (AB), which is likely eroded metamorphic basement rocks based on the ODP sonobuoy velocity of $5.7 \mathrm{~km} / \mathrm{s}$. See Figure 1 for location. $\mathrm{M}=$ multiple.

PS.1 or PS.2A. Unit PS.1 reaches thicknesses in excess of $200 \mathrm{~m}$, and is thickest in the northeastern part of Prydz Bay where water depths are shallowest. Thicknesses of unit PS.1 are undefined or uncertain (1) on the outermost continental shelf, where the angular unconformity defining the base of unit PS.1 be- comes conformable with unit PS.2A, and (2) on the innermost and western shelf, where the unit is too thin to be resolved in low-frequency seismic reflection profiles. The source area and precise mode of deposition for glacially derived rocks of unit PS.1 are unknown, yet the systematic northeast thickening of 


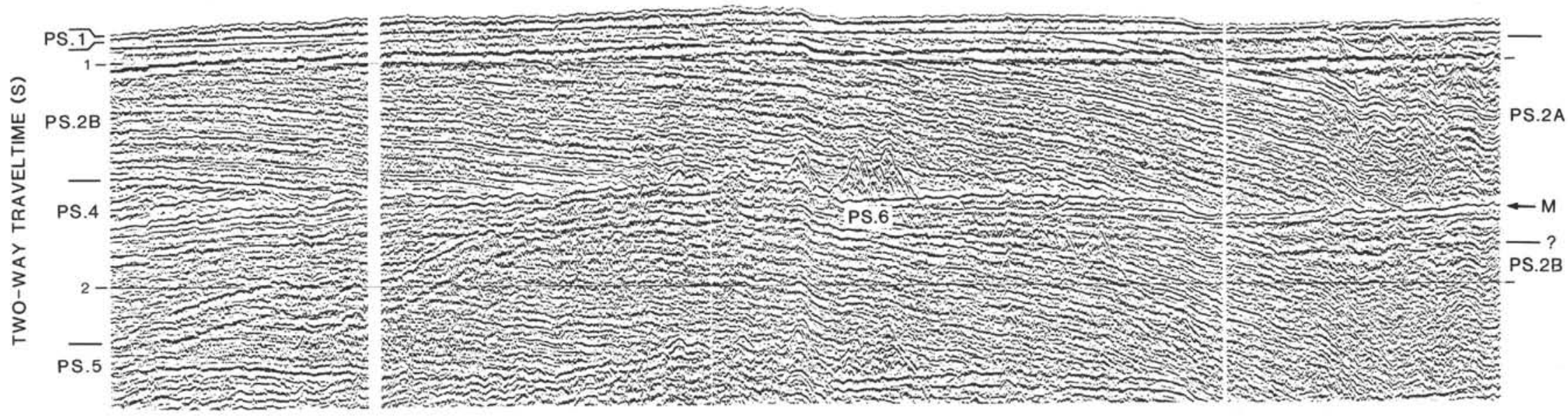

Figure 11. Line PB-27 segment showing the angular unconformity separating units PS.2B and PS.4 on the northern flank of Prydz Bay basin. Here, we suspect that metamorphic basement (unit PS.5; the deep, smooth, strong reflection) is intruded by strongly magnetic rocks (unit PS.6; irregular basal reflection) at the crest of the basement high that delineates the northern edge of Prydz Bay basin. See Figure 1 for location. $M=$ multiple. 


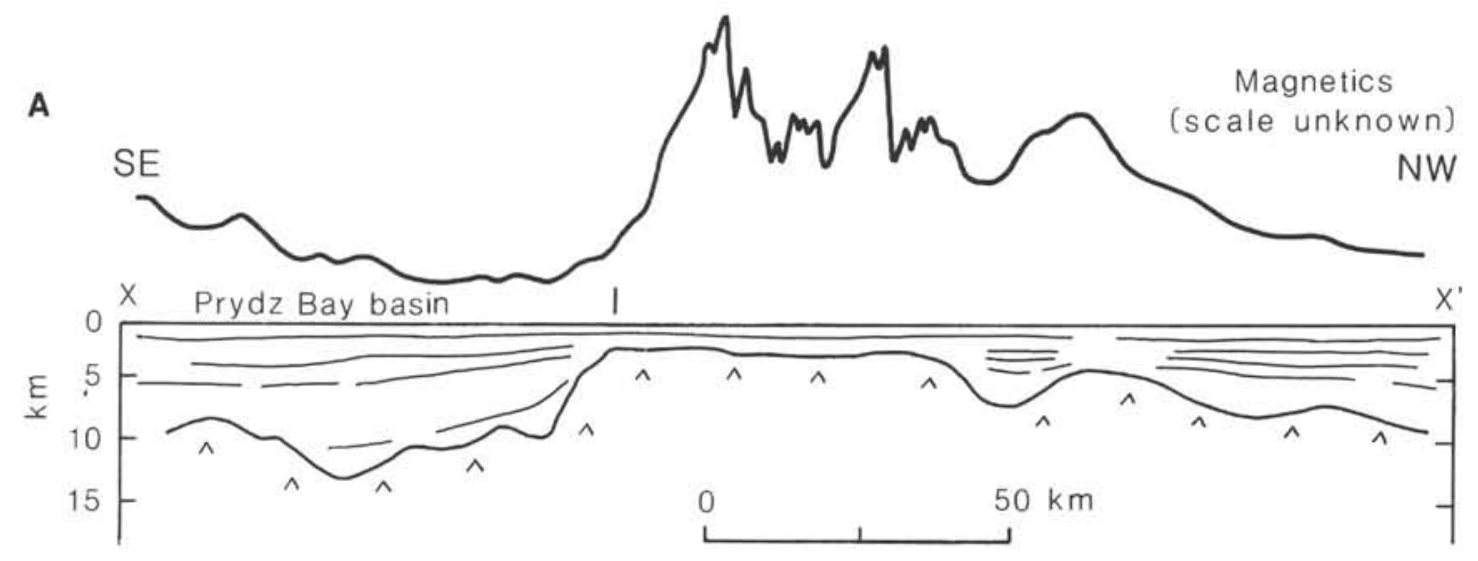

B

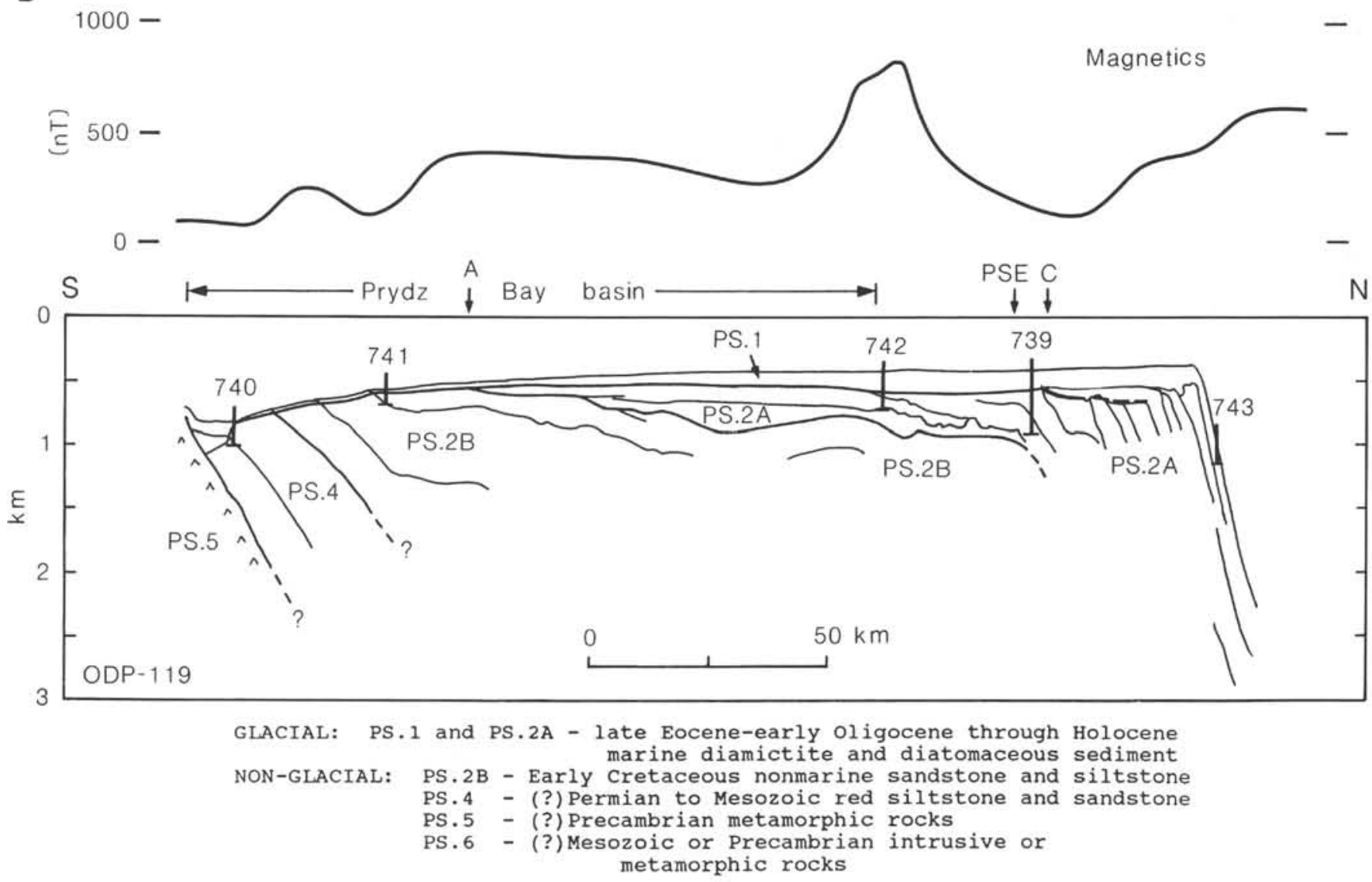

Figure 12. Depth sections (in kilometers) with magnetic profiles for Prydz Bay. A. Section $\mathrm{X}-\mathrm{X}^{\prime}$ across the midshelf basement high (modified from Shelestov and Alyavdin, 1987). B. Line ODP-119, based on Figure 3B and sonobuoy velocity data at Prydz Bay drill sites from Cochrane and Cooper (this volume). $\mathrm{A}$ and $\mathrm{C}$ are reference points. See Figure 1 for location. PSE = paleo-shelf edge.

well-layered topset horizons within unit PS.1 suggests a sediment source carried by grounded ice originating in the southwest (i.e., from a more extensive paleo Amery Ice Shelf). We suspect that the areas where unit PS.1 is thickest either were not covered by grounded ice and the remnant topset beds were deposited in front of a grounded ice sheet, or were covered by grounded ice and the topset beds were preserved by subsidence of the outermost continental margin. In either case, these topset beds were not significantly eroded by subsequent grounded ice sheets that may have traversed the shelf.
The subcrop pattern of acoustic units directly beneath unit PS.1 (Fig. 13C) is in part structurally controlled. The pattern sub-parallels the axis of the Prydz Bay basin and the coastline of Princess Elizabeth Land, which are believed to be fault-controlled (Fig. 13D; Stagg, 1985). Although the prograding glacial rocks of unit PS.2A can be traced as thin beds (less than $100 \mathrm{~m}$ thick) to within $70 \mathrm{~km}$ of shore near Davis Station, the greatest thickness of glacial debris lies beneath the outer shelf seaward of the basement high and buried paleo-shelf edge near Site 739 (PSE, Fig. 12). Prograding glacial sequences of the outer conti- 

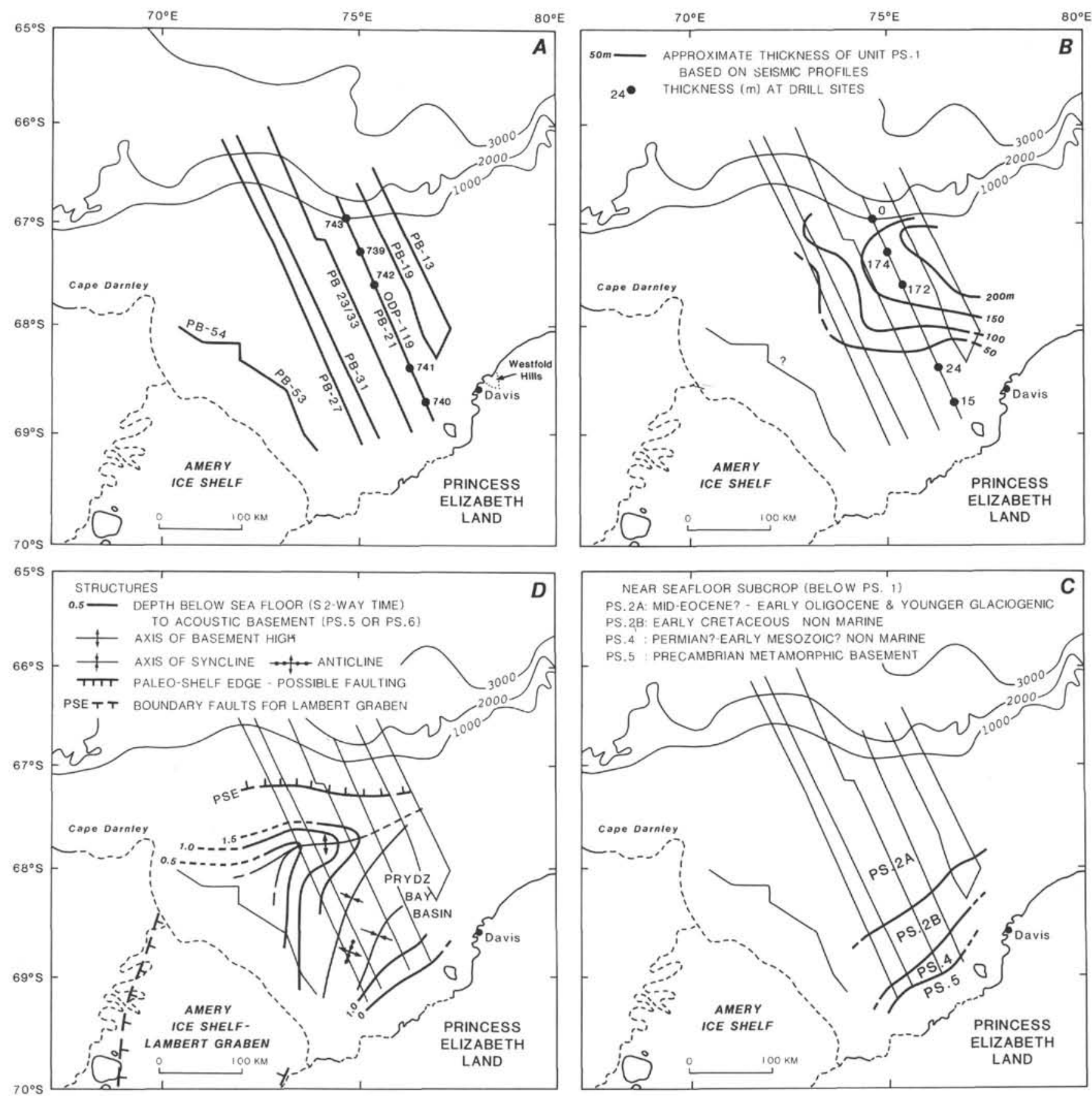

Figure 13. Maps of Prydz Bay showing distribution of sedimentary and structural features. A. Bathymetric index map. B. Approximate thickness contours (in meters) for unit PS.1. C. Subcrop pattern of the acoustic units that lie directly below unit PS.1 (i.e., the pattern if unit PS.1 were to be removed). Nearly two-thirds of Prydz Bay is covered by more than $50 \mathrm{~m}$ of glacial rocks of unit PS.2A. D. Thickness contours (s two-way traveltime) to the top of unit PS.5 (metamorphic basement). The contours converge to the southwest indicating that Prydz Bay basin may be structurally separate from the Lambert Graben.

nental shelf (PS.2A) extend over larger areas in the western part of Prydz Bay, as evidenced by the divergence of the paleo- and present-day shelf edges west of Site 739 (Fig. 13D). However, the thickness and extent of units PS.1 and PS.2A over much of western Prydz Bay (i.e., west of PB-27) is less certain because of limited seismic control and greater structural deformation near the Lambert Graben.

\section{Seismic Structures of Prydz Bay}

The major structural features of the Prydz Bay region have been discussed previously (Stagg, 1985; Shelestov and Alyavdin, 1987) and are newly interpreted by us in a map (Fig. 13D) and cross section (Fig. 12). In general, structural features are larger, more numerous, and shallower (i.e., more easily identified) in 
the western part of Prydz Bay, near the Lambert Graben, than in the east, within the Prydz Bay basin.

A major basement high traverses Prydz Bay from the offshore terminus of the Lambert Graben northeast to the middle of the shelf, and delineates the northern edge of the Prydz Bay basin. We, like Masolov et al. (1981) and Stagg (1985), believe that Prydz Bay basin may be structurally separate from the Lambert Graben, based on the southwest convergence and closure(?) of the structural contours near the northeast end of the onshore Lambert Graben (Fig. 13D). Seismic reflection profiles generally show only minor structural deformation in the northeast part of Prydz Bay basin, consisting of gentle folding and few small faults in the sedimentary section. Basement faulting and local folding of the sedimentary section increases to the southwest. Intense faulting at the seafloor (late Cenozoic?) is observed in several profiles across the offshore projection of the Lambert Graben (e.g., PB-54; Stagg, 1985). The extent of the intense faulting is unknown, but is not seen in most lines crossing Prydz Bay (e.g., PB-13 to PB-27).

Thickness of sedimentary strata up to $12 \mathrm{~km}$ have been estimated for Prydz Bay basin, based on estimates of depth to magnetic basement (Masolov et al., 1981; Fedorov et al., 1982) and seismic refraction and gravity model studies (Fig. 12A; Shelestov and Alyavdin, 1987). Simple downward projection of dips measured along line ODP-119 using sonobuoy velocity-depth curves of Cochrane and Cooper (this volume) suggests that at least $5 \mathrm{~km}$ of strata lie within the basin (Fig. 12). Seaward of the midshelf basement high (i.e., seaward of Site 742), the geometry of basement structures and preglacial rocks as well as the total thickness of glacial strata are unknown. Mizukoshi et al. (1988) show a $3.5 \mathrm{~km}$ thickness for likely sedimentary rocks (sonobuoy $\mathrm{J} 7$, refraction velocities less than $5.0 \mathrm{~km} / \mathrm{s}$ ) about $42 \mathrm{~km}$ seaward of the basement-high axis and close to line PB-27 (Fig. 1B). Further thickening of the glacial strata to more than $6 \mathrm{~km}$ beneath the outer shelf is possible, based on projection of nearsurface dips along line PB-27. Stratal dips are steeper along line PB-21 and more difficult to project. At least 3 to $5 \mathrm{~km}$ of strata younger than late Eocene to early Oligocene is likely beneath the outermost shelf and upper slope along PB-21.

The abrupt change in dip of reflections that occurs a few kilometers landward of Site 739 (PSE, Figs. 4 and 12) can be mapped in all seismic reflection profiles crossing the shelf and is in part structurally controlled. To the west of Site 739, the dip change becomes more abrupt, and strata become more disrupted as the underlying deformation apparently increases. We interpret the abrupt dip change as a paleo-shelf edge for which the position was controlled, in part, by down-faulting of underlying basement rocks. Part of the apparent deformation may have resulted from sediment failures along the front of the rapidly developing and prograding marine glacial sequences situated at the paleo-shelf edge.

\section{DISCUSSION}

\section{Paleo-Depositional Environments}

\section{Preglacial}

ODP drill cores from Sites 740 and 741 confirm previous speculations (Fedorov et al., 1982; Stagg, 1985) that the Prydz Bay basin (and probably the Lambert Graben) contains preglacial, continental strata that were likely deposited in rift basins associated with Gondwana breakup. Seismic reflection profiles indicate that these strata, especially unit PS.2B, change in acoustic character across the shelf, suggesting to us different depositional environments within the rift basin. Figure 14 shows a conceptual model modified from Etheridge (1988) illustrating the variety of nonmarine to marine depositional environments

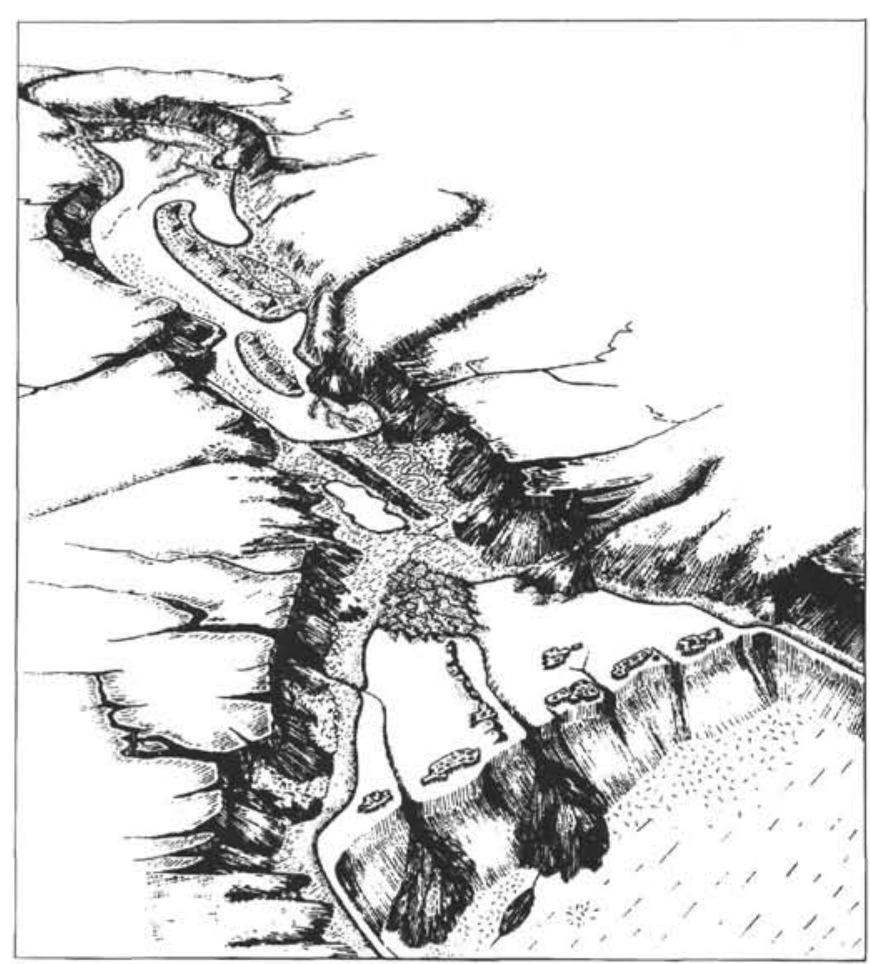

Figure 14. Conceptual model of a narrow rift graben system at a continental margin showing likely fluvial, deltaic, and shallow-marine depositional environments (modified from Etheridge et al., 1988).

that might be expected in a narrow rift system at the edge of a continent prior to glaciation.

With our limited seismic reflection data, we can only speculate on broad depositional environments on the Prydz Bay shelf. Within unit PS.2B, these environments appear to change areally from fluvial nonmarine on the inner shelf (i.e., near Site 741) to alluvial plain and possibly shallow marine beneath the present midshelf area (near Site 742). Over this area, the continuity and amplitude of reflections increases seaward. The highly discontinuous reflectors at Site 741 grade into well-defined reflectors that are more typical of the marine environment (see Fig. 2, back pocket).

Sedimentary units PS.4 and PS.2B also show gradual vertical changes in reflection character indicating environmental variations with time. Yet there is little evidence in the data for rapid lateral or vertical changes in the acoustic units (within the approximate $10-\mathrm{m}$ resolution of the seismic reflection data) that might be expected in high-energy river or delta environments. Rather, changes appear gradual and indicative of low-energy floodplain and gently sloping sites. Some disruption of reflectors is observed within the flat-lying, midshelf sections of unit PS.2B near ODP-line 119; however, a great part of this appears to be caused by caused by seismic noise derived from irregularities in overlying glacigenic rocks.

The basal contact of unit PS. 4 with underlying unit PS.5 appears to be an erosional unconformity. The relatively smooth upper surface of unit PS.5, which we interpret as the top of metamorphic basement, occurs regionally (Figs. 9, 10, and 11) suggesting broad uplift and high-energy erosion prior to deposition of the continental rift graben strata of unit PS.4

\section{Glacial}

Where units PS.1 and PS.2A were sampled beneath the outer continental shelf (i.e., at Sites 742,739 , and 743 ), they are prin- 
cipally composed of marine glacial diamictites, but they also include sediments of likely interglacial or nonglacial origin (i.e., diatom oozes, silt, and sand units; Barron, Larsen, et al., 1989). The sampled glacial and interbedded interglacial(?) rocks have similar reflection characteristics that depend upon bed thickness and degree of compaction (Figs. 4 and 5). Thus, the origins (i.e., glacial to non-glacial) of the vast unsampled portions of these prograding sequences cannot be determined from the seismic data, and are equivocal. We suspect that the units are principally glacigenic based on several observations:

1. Paleo-depositional fronts, as defined by the strike of seaward-dipping strata beneath the outer continental shelf, are more linear than lobate across most of Prydz Bay. This geometry is consistent with deposition in front of an extensive grounded ice sheet at the continental shelf edge (Fig. 15; Hambrey et al., this volume). A lobate front exists at the present-day shelf edge at the end of the north-south channel that crosses the shelf (Fig. 1A). Strata dip less steeply beneath this front than in areas to the east and unit PS.1 is thin or missing. These characteristics suggest to us more localized, rapid deposition in front of, and erosion beneath, a former ice stream within the seaward extension of the Amery Ice Shelf (i.e., to the continental shelf edge).

2. The topset beds of the prograding sequences beneath most of the mid- to outer shelf are thin or missing, making the sequences appear to build principally outward (i.e., seaward), rather than upward and outward. The prograding geometry is characteristic of other Antarctic shelves (Hinz and Block, 1983; Haugland et al., 1985; Cooper and Davey, 1987; Larter and Barker, 1989; Alley et al., 1989; Cooper et al., in press) and Arctic (Vorren et al., 1989) shelves that also are believed to have experienced deposition from grounded ice sheets. This geometry can be explained by erosion and deposition by grounded ice sheets moving back and forth across the shelf (Fig. 15; Hambrey et al., this volume; Solheim et al., chapter 9, this volume).

3. Similarities can be seen in the overall geometry of reflection sequences bounded by unconformities within unit PS.2A on several seismic lines across Prydz Bay (i.e., over distances exceeding $100 \mathrm{~km}$ ). The similarities suggest that sea-level and glacial ice fluctuations are regionally affecting depositional processes.

4. Reflections caused by the glacial strata of unit PS.2A at Site 739 have a similar semidisrupted character to those of dipping reflections of unknown origin farther seaward. This criterion is, however, less reliable, for reasons noted previously.
The history of likely glacial and interglacial events within the unit PS.2A prograding sequences cannot accurately be determined from ODP drilling and seismic reflection data, principally because: (1) core recovery was low (22\% to $53 \%)$ at all Prydz Bay drill sites; (2) the few datable beds within unit PS.1 at Site 739 are too thin to be traced reliably seaward more than a few kilometers in seismic profiles, to the point where they probably merge with unit PS.2A and become part of the dipping unit; and (3) numerous unconformities exist within unit PS.2A and delineate separate sequences. We can reliably say that nearly all of unit PS.2A is younger than late Eocene to early Oligocene age. We speculate from seismic data that (1) the outermost 8 to $10 \mathrm{~km}$ of the prograding sequence may be younger than late Miocene age, based on tracing nearly flat reflections seaward from Site 739 (120 mbsf, Figs. 4, 5, and 2, back pocket), and (2) widespread glacial rocks may lie below the late Eocene to early Oligocene age rocks sampled at Sites 739 and 742 . (i.e., reflectors at the bottom of these holes can be traced about $80 \mathrm{~km}$ landward from Site 742 (point A, Fig. 12), where they are truncated against unit PS.1, and about $5 \mathrm{~km}$ seaward from Site 739, where they disappear into the seafloor multiple (point C, Fig. 12). Further drilling or sampling of PS.2A is required to resolve the glacial and interglacial history younger than late Eocene to early Oligocene time.

Downhole velocity logs and seismic reflection profiles provide indirect evidence of depositional environments in the vicinity of Sites 739 and 742 . In-situ rock velocity measurements show that highly variable velocity gradients generally correlate with discontinuous reflections (i.e., 175 to 325 mbsf at Site 739, Fig. 5), and probably represent relatively high-energy environments compatible with the upper-slope front of a prograding glacial sequence. Where in-situ velocities vary more smoothly and have discrete 1- to 3-m-thick low-velocity sand(?) layers (i.e., 325 to 487 mbsf at Site 739), reflections are mostly continuous, indicating a relatively low-energy environment such as the distal and deeper water parts of a prograding glacial sequence.

Ice sheets, such as proposed by Hambrey et al. (this volume) (Fig. 15) and Solheim et al. (chapter 9, this volume), apparently covered most of Prydz Bay intermittently. Several grounding events are recorded on the outer shelf at Site 739 (Solheim et al., chapter 9, this volume), and grounding has also occurred beneath the innermost shelf (in water depths up to $1000 \mathrm{~m}$ ) based partly on the near-seafloor erosion of units PS.2B and PS.4. The seismic reflection evidence for ice grounding near the present-day continental shelf edge is, however, equivocal because

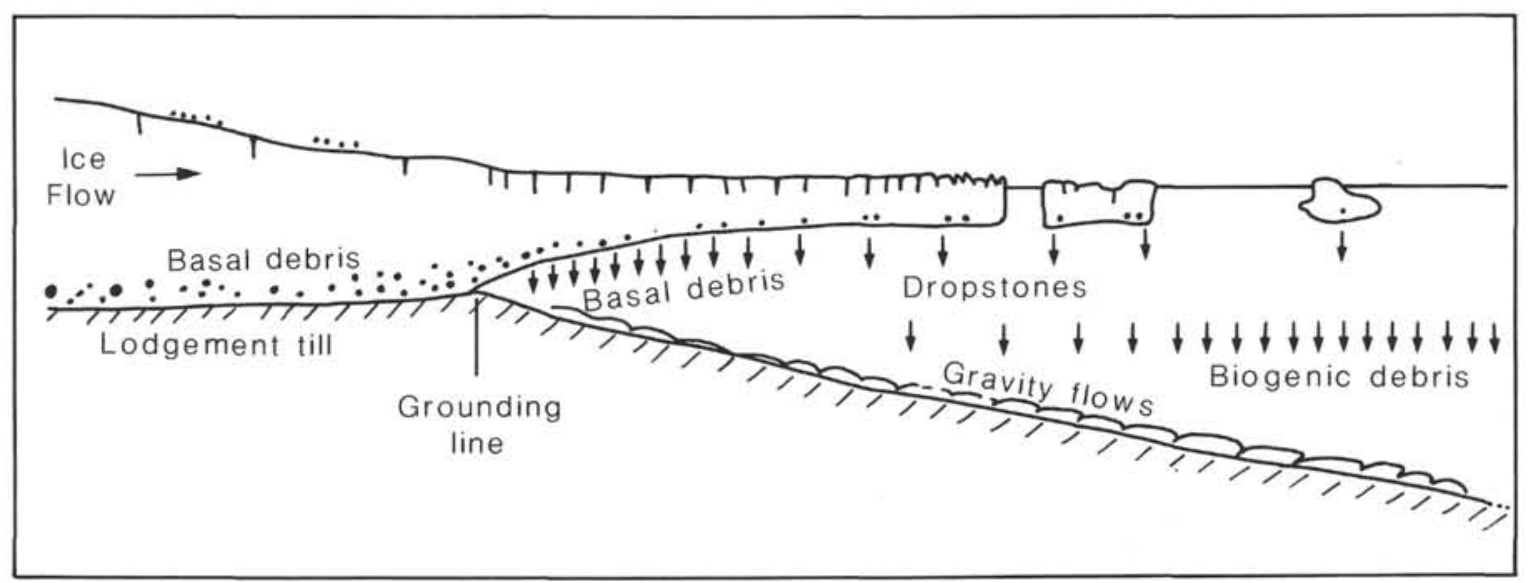

Figure 15. Conceptual model of depositional environments associated with a grounded and moving ice sheet (modified from Hambrey et al., this volume). 
unit PS. 1 is not well defined (i.e., the flat-lying zone of discontinuous reflections indicative of diamictites, as at Site 739 , is not clearly visible). Yet, glacial diamictons recovered at Site 743 on the upper continental slope are believed to be from a grounded ice sheet (Hambrey et al., 1989; Barron, Larsen, et al., 1989).

The principal source of the ice (and entrained sediment?) is probably the vast Lambert Glacier system, which drains nearly $22 \%$ of the East Antarctic ice sheet. This system has carved the bathymetric trough across Prydz Bay (Fig. 1A) and has produced a local lobate prograding apron near the seaward end of the trough. Significant ice movement laterally across other parts of the shelf is likely, based on the thickness contours of unit PS.1 (Fig. 13B), but the extent of this movement and its effect on forming the prograding glacial sequences along the entire Prydz Bay outer shelf is unknown.

\section{Evolution of Prydz Bay}

The origin of the Prydz Bay region has long been attributed to the Mesozoic breakup of Gondwana (du Toit, 1937; Fedorov et al., 1982; Stagg, 1985), based almost entirely on geometric arguments in the absence of widespread geologic data. ODP drilling provides the first evidence for in-situ late Paleozoic(?) and younger sedimentary strata to constrain evolutionary models for offshore basins. Unfortunately, the age of the oldest continental rift basin deposits from Prydz Bay basin are unknown (Site 740), although Early Cretaceous deposits have been recovered from the basin (Site 741; Barron, Larsen, et al., 1989; Truswell, this volume). The seismic reflection data remain the best source for ascertaining the relative timing of events in the structural evolution of Prydz Bay basin.

Stagg (1985) describes Prydz Bay basin and Lambert Graben as a failed rift arm of a triple junction that formed during the initial breakup of Gondwana. He infers a history of rifting from regional geologic data and the Gondwana reconstruction of Smith and Hallam (1970; Fig. 16;), which is consistent with more recent reconstructions (Lawver et al., in press) placing the transverse coastal grabens of India against Prydz Bay.
Stagg (1985) rift history includes:

1. A rift onset unconformity of Permian to Early Cretaceous age (between units PS.4 and PS.5) that erodes underlying Permian strata;

2. Mesozoic rift units (PS.3 and PS.4);

3. A margin breakup unconformity (between units PS.2 and PS.4);

4. A prograding early Cretaceous to mid-Cenozoic shallow marine unit (PS.2); and

5. A post-mid-Miocene tillite (PS.1).

Our revised rift history include a similar history as Stagg (1985) with three important differences:

1. The rift onset unconformity erodes metamorphic basement (our unit PS.5) and not Permian strata. The fluvial redbed strata of possible late Paleozoic or early Mesozoic age at Site 740 were deposited on this unconformity.

2. During breakup, magmatic rocks may have been emplaced beneath parts of Prydz Bay (our unit PS.6).

3. A newly recognized major unconformity exists between unit PS.2B (continental rift deposits) and unit PS.2A (glacialmarine rocks) and represents the onset of major continental glaciation in East Antarctica.

Other differences are minor and noted below.

\section{Proposed Evolutionary Model}

Figure 17 presents our conceptual model for the evolution of Prydz Bay, using the new seismic and drilling results along line ODP-119 to constrain the relative timing of major events.

We, like the previous investigators, relate the major unconformities in the offshore sedimentary section to rifting events of Gondwana breakup. The earliest time of Gondwana rifting is poorly constrained in the Prydz Bay region. As noted above, erosion of the rift-onset unconformity along the top of meta-

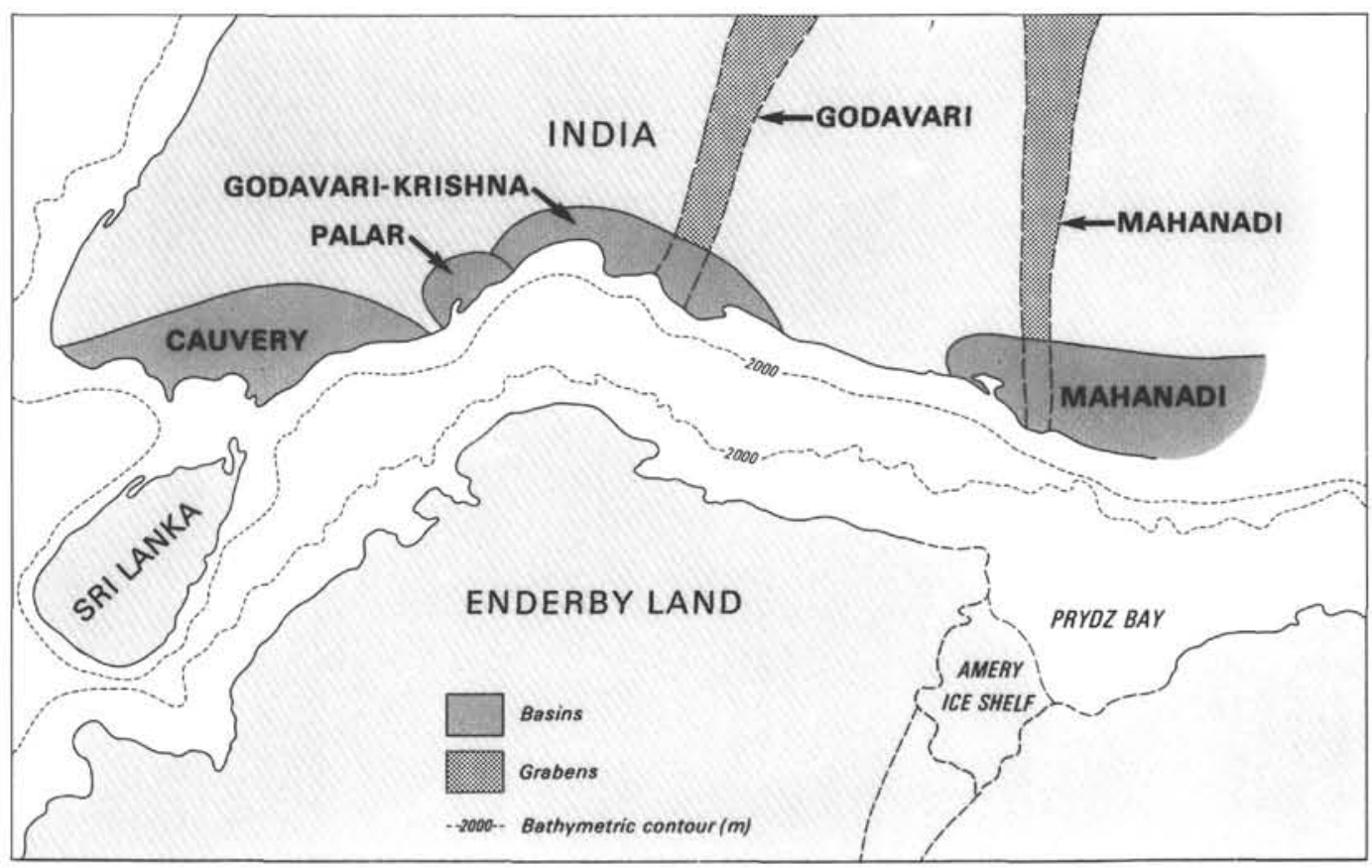

Figure 16. Reconstruction of Gondwana showing locations of early Paleozoic and younger rift graben systems of India and Antarctica (from Stagg, 1985). 


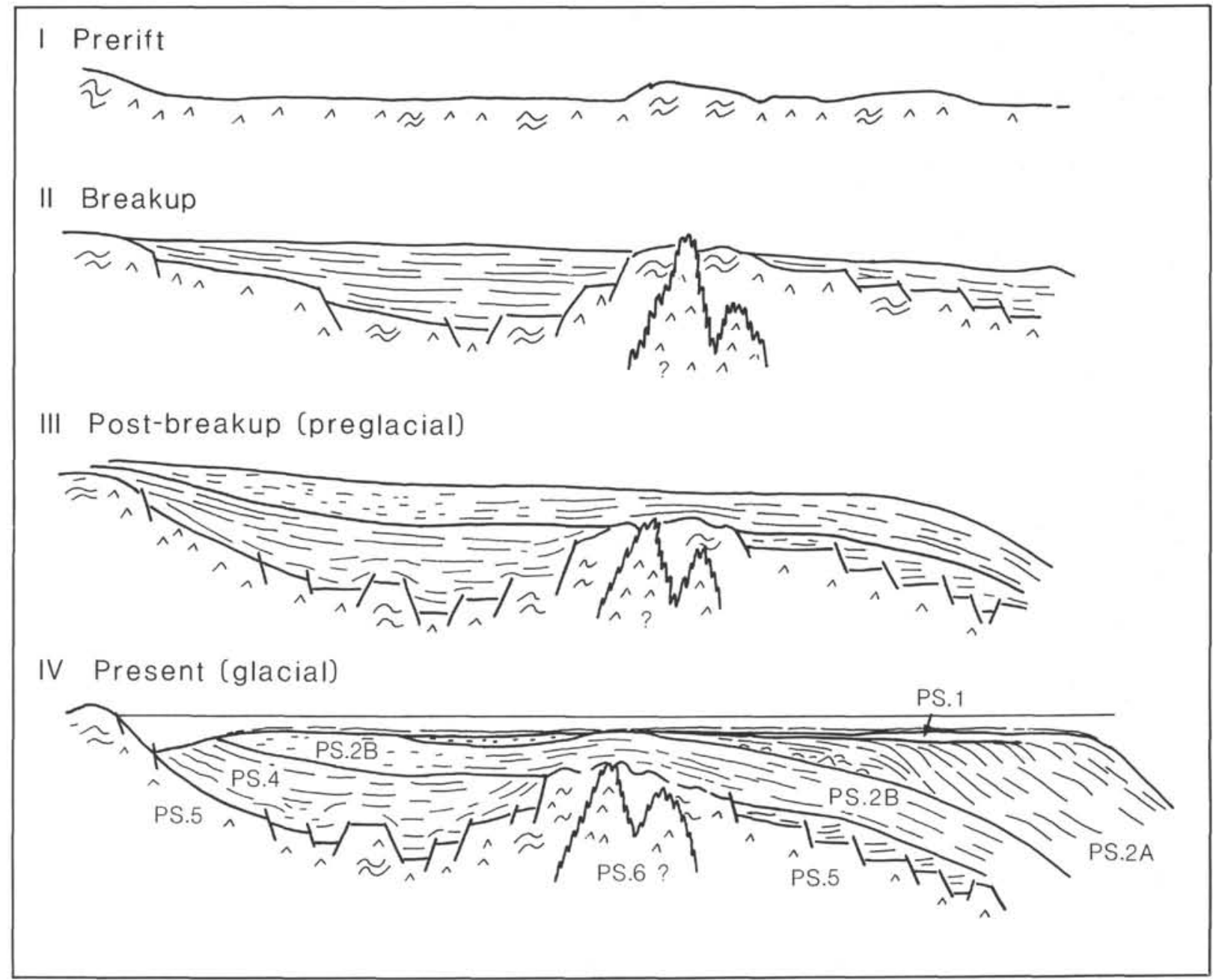

$$
\begin{aligned}
& \text { GLACIAL: PS. } 1 \text { and PS.2A - late Eocene-early Oligocene through Holocene } \\
& \text { marine diamictite and diatomaceous sediment } \\
& \text { NON-GLACIAL: PS.2B - Early Cretaceous nonmarine sandstone and siltstone } \\
& \text { PS. } 4 \text { - (?) Permian to Mesozoic red siltstone and sandstone } \\
& \text { PS. } 5 \text { - (?) Precambrian metamorphic rocks } \\
& \text { PS. } 6 \text { - (?) Mesozoic or Precambrian intrusive or }
\end{aligned}
$$

Figure 17. Our conceptual model for the evolution of Prydz Bay based on seismic stratigraphic and drilling data. I. Pre-rift (early Paleozoic?) - widespread uplift and erosion of metamorphic basement prior to rifting. II. Breakup (Early Cretaceous, Valanginian?)-marks the end of downfaulting and filling of grabens of the early rift phase. Possible intrusion of mafic rocks along midshelf basement high. III. Post breakup, preglacial (Early Cretaceous, Albian?)-a period of rapid deposition of nonmarine to marine rocks following breakup, burying older rift deposits. IV. Present, glacial-the onset of East Antarctic continental glaciation (late Eocene to early Oligocene) eroded inner shelf sequences and initiated deposition of major prograding glacial sequences on the outer continental shelf.

morphic basement (I, Fig. 17) predates the deposition of the Permian(?) and younger(?) strata of unit PS.4 sampled at Site 740. These strata may have been deposited in a similar tectonic setting to the formerly adjacent Mahanadi and Godovari rift grabens of peninsular India, where Permian to Early Cretaceous continental strata are found (Sastri et al., 1974; Basu and Shrivastava, 1981). The likely Paleozoic age of this unconformity is consistent with that suggested for rifting of the contiguous Lambert Graben (Fedorov et al., 1982), but is considerably older than the Early Cretaceous age of the Gondwana breakup inferred from plate reconstructions (Johnson and Veevers, 1984; Lawver et al., in press) and from drilling by Legs 119 and 120 on nearby Kerguelen Plateau (Barron, Larsen, et al., 1989; Wise et al., 1989).

The large thickness of unit PS.4 (probably in excess of $5 \mathrm{~km}$ in the center of the basin) greatly exceeds that for Permian rocks in the Lambert Graben (Mond, 1972) suggesting a broader range in age than solely Permian for the continental rift deposits in Prydz Bay basin. These strata of the early rifting phase (i.e., prior to breakup) may have accumulated in rapidly subsiding basins like the shelf basins of Australia (Falvey and Mutter, 1981). A coeval early-rift sedimentary section is also likely in basement grabens seaward of the midshelf basement high (II, Fig. 17), although this section cannot be resolved on seismic re- 
flection data. Significantly, the widespread rift-onset unconformity at the top of unit PS.5 likely represents the earliest stage of Gondwana rifting in late Paleozoic to early Mesozoic time.

Continental separation and initiation of seafloor spreading between India and Antarctica (128 Ma; Johnson and Veevers, 1984 ) is probably recorded by a breakup unconformity between units PS.4 and PS.2B (II, Fig. 17; Stagg, 1985). This interpretation is consistent with recovery of Early Cretaceous age (about $100 \mathrm{Ma}$, Albian) nonmarine strata at Site 741 . Up to $3 \mathrm{~km}$ of mostly undeformed strata of unit PS.2B drape across the shelf between the breakup unconformity and the horizon at the base of Site 741 (Fig. 12). The large thickness implies relatively rapid deposition in a restricted basinal setting (Fig. 14) following breakup, such as observed on other Gondwana margins (i.e., Australia-Falvey and Mutter, 1981; Etheridge et al., 1988). The breakup may also have been associated with emplacement of the strongly magnetic rocks that intrude the midshelf basement high, as inferred from magnetic and seismic data. Alkalic igneous intrusives of Cretaceous age (110 Ma) occur rarely in the nearby Prince Charles Mountains (and in formerly adjacent Gondwana basins of eastern India; Sheraton, 1983). These onshore intrusives may be related to those suspected offshore.

Following the breakup, the onset of East Antarctic continental glaciation (III and IV, Fig. 17). is marked by another major unconformity between the continental rift deposits (unit PS.2B) and glacial strata (units PS.2A and PS.1). The unconformity is inferred based on the large age difference (but small vertical separation) between the Early Cretaceous age strata at Site 741 and late Eocene to early Oligocene age rocks at Site 742. A seismic discontinuity between Sites 741 and 742 is mapped as the glacial-onset unconformity (Fig. 12). All rocks above the unconformity are of glacial (or interglacial) origin.

An unknown thickness of strata, probably up to $1 \mathrm{~km}$, has been uplifted and eroded from the inner shelf, as evidenced by truncated dipping beds and high acoustic velocities close to the seafloor (Cochrane and Cooper, this volume; Solheim et al., chapter 9, this volume). The mechanism for uplift is unclear, but may be related to isostatic effects caused by ice unloading and active glacial erosion of high-standing areas (Wellman and Tingey, 1981; Tingey, 1985). These authors postulate $0.8 \mathrm{~km}$ of uplift in the Prince Charles Mountains, and less in the Vestfold Hills. Erosion of the inner shelf, most recently in late Cenozoic time, was by grounded ice sheets (Hambrey et al., this volume). The glacial sequences that have prograded the shelf edge seaward more than 39 to $55 \mathrm{~km}$ were deposited since about late Eocene-early Oligocene time.

\section{SUMMARY}

Recent ODP drilling in Prydz Bay has provided age and lithology data for acoustic units and structures that we have newly mapped and interpreted on the basis of reprocessed seismic data of Stagg (1985). Six acoustic units (PS.1 to PS.6) are mapped, but only three were drilled.

Inner Prydz Bay is underlain by a deep sediment-filled rift basin that is contiguous to, but separated from, the major Lambert Rift Graben. More than $5 \mathrm{~km}$ of Early Cretaceous and older continental rift strata probably lie within Prydz Bay basin. A glacially dominated unit of late Eocene-early Oligocene and younger age unconformably overlies the rift strata. The glacial unit is a major prograding feature that underlies nearly the entire outer shelf. Major unconformities separate all acoustic units, but only one has been drilled (i.e., the unconformity at base of unit PS.1). We attribute the acoustic unconformities either to rift events (rift-onset unconformity, units PS.5 to PS.4; breakup unconformity, units PS.4 to PS.2B) or to glacial erosion (onset of continental East Antarctic glaciation, units PS.2B to PS.2A; movement of grounded ice sheets, unit PS.1 to underlying units).
Other unconformities exist within the prograding glacial sequence, but cannot be mapped regionally with existing seismic data.

Prydz Bay basin probably formed in late Paleozoic time during the earliest Gondwana rifting, which affected nearby parts of Antarctica (Lambert Rift) and India (Mahanadi Rift), based on possible Permian and early Mesozoic age strata at Site $\mathbf{7 4 0 .}$ The basin formed behind an outer basement high that may later have been intruded by strongly magnetic rocks during the Early Cretaceous margin breakup. Rapid sedimentation of up to 3-4 $\mathrm{km}$ of Early Cretaceous and younger nonmarine rocks, such as recovered at Site 741, followed the breakup. An unknown thickness of this section was eroded from the inner shelf by grounded ice sheets and was redeposited, together with younger rocks, in the glacigenic sequences that have moved the shelf edge seaward up to $55 \mathrm{~km}$ since late Eocene to early Oligocene time.

\section{ACKNOWLEDGMENTS}

We wish to thank our ODP colleagues aboard Leg 119, at the Lamont-Doherty downhole logging center, and at College Station headquarters for helpful post-cruise discussions and information, in particular J. Barron, B. Larsen, J. Baldauf, M. Hambrey, G. Ollier, M. Hobart, R. Gerrard, K. Benson, and K. Lighty. We appreciate the support of the Bureau of Mineral Resources in facilitating and underwriting reprocessing of the Prydz Bay seismic data. We also wish to thank our colleagues G. Grikurov and G. Leitchenkov of the Soviet Union and Y. Tamura of Japan for access to unpublished data and maps for the Prydz Bay region. Helpful reviews of the manuscript were provided by B. Larsen, M. Hambrey, G. Cochrane, P. Barker, L. Bartek, and J. Anderson. Part of this work was done under a travel grant from NSF-USSAC, whose support is greatly appreciated.

\section{REFERENCES}

Adamson, D. A., and Pickard, J., 1986. Cainozoic history of the Vestfold Hills. In Pickard, J. (Ed.), Antarctic Oasis: Terrestrial Environments of the Vestfold Hills: New York (Academic Press), 63-98.

Alley, R. B., Blankenship, D. D., Rooney, S. T., and Bentley, C. R., 1989. Sedimentation beneath ice shelves -the view from Ice Stream B. Mar. Geol., 85:101-120.

Bardin, V. I., 1982. Composition of East Antarctic moraines and some problems of Cenozoic history. In Craddock, C. (Ed.), Antarctic Geoscience: Madison (Univ. of Wisconsin Press), 1069-1076.

Barron, J., Larsen, B., et al., 1989. Proc. ODP, Init. Repts., 119: College Station, TX (Ocean Drilling Program).

Basu, T. N., and Shrivastava, B.B.P., 1981. Structure and tectonics of Gondwana basins of peninsular India. In Cresswell, M. M., and Vella, P. (Eds.), Gondwana Five: Rotterdam (A. A. Balkema), $177-$ 182.

BMR, 1989. Multichannel seismic-reflection data from Prydz Bay, Antarctica. Data Availability Announcement: Canberra (BMR Div. Mar. Geosciences)

Collerson, D. D., and Sheraton, J. W., 1986. Bedrock geology and crustal evolution of the Vestfold Hills. In Pickard, J. (Ed.), Antarctic Oasis: Sydney (Academic Press), 21-62.

Cooper, A. K., and Davey, F. J. (Eds.), 1987. The Antarctic Continental Margin: Geology and Geophysics of the Western Ross Sea: Houston (Circum-Pacific Council for Energy and Mineral Resources), Earth Sci. Ser., Vol. 5B

Cooper, A. K., Barrett, P. J., Hinz, K., Traube, V., Leitchenkov, G., Stagg, H.M.J., in press. Cenozoic prograding sequences of the Antarctic continental margin: A record of glacio-eustatic and tectonic events, Mar. Geol.

du Toit, A. L., 1937. Our Wandering Continents: an Hypothesis of Continental Drifting. Edinburgh (Oliver and Boyd).

Etheridge, M. A., Symonds, P. A., and Powell, T. G., 1988. Application of the detachment model for continental extension to hydrocarbon exploration in extensional basins. APEA J., 28:167-188.

Falvey, D. A., and Mutter, J. C., 1981. Regional plate tectonics and the evolution of Australia's continental margins. BMR J. Aust. Geol. Geophys., 6:1-29. 
Federov, L. V., Grikurov, G. E., Kurinin, R. G., and Masolov, V. N., 1982. Crustal structure of the Lambert Glacier Area from geophysical data. In Craddock, C., Loveless, J. K., Vierima, T. L., and Crawford, K. (Eds.), Antarctic Geoscience: (Univ. Wisconsin Press), 931-936.

Hambrey, M. J., Larsen, B., Ehrmann, W. U., and ODP Leg 119 Shipboard Scientific Party, 1989. Forty million years of Antarctic glacial history yielded by Leg 119 of the Ocean Drilling Program. Polar Rec., 25:99-106.

Haugland, K., Kristoffersen, Y., and Velde, A., 1985. Seismic investigations in the Weddell Sea embayment. Tectonophysics, 114:293-313.

Hinz, K., and Block, M., 1983. Results of geophysical investigations in the Weddell Sea and in the Ross Sea, Antarctica. Proc. 11th World Petroleum Congress (London), 2:1-13.

Johnson, B. D., and Veevers, J. J., 1984. Oceanic paleomagnetism. In Veevers, J. J., et al., (Eds.), Phanerozoic Earth History of Australia: Oxford (Oxford Univ. Press), 17-42.

Kurinin, R. G., and Grikurov, G. E., 1982. Crustal structure of part of East Antarctica from geophysical data. In Craddock, C. (Ed.), Antarctic Geoscience: Madison (Univ. of Wisconsin Press), 895-902.

Larter, R. D., and Barker, P. F., 1989. Seismic stratigraphy of the Antarctic Peninsula Pacific margin: A record of Pliocene-Pleistocene ice volume and paleoclimate. Geology, 17:731-734.

Lawver, L. A., Royer, J., Sandwell, D. T., and Scotese, C. R., in press. Evolution of the Antarctic continental margins. In Thompson, M. A., Crame, J. A., and Thompson, J. W. (Eds.), Geological Evolution of Antarctica: Cambridge (Cambridge Univ. Press).

Leg 119 Shipboard Scientific Party, 1988. Early glaciation of Antarctica. Nature, 333:303-304.

Masolov, V. N., Kurinin, R. G., and Grikurov, G. E., 1981. Crustal structures and tectonic significance of Antarctic rift zones (from geophysical evidence). In Cresswell, M. M., and Vella, P. (Eds.), Gondwana Five: Rotterdam (A. A. Balkema), 303-309.

Mizukoshi, I., Sunouchi, H., Saki, T., Sato, S., and Tanahashi, M., 1988. Preliminary report of geological and geophysical surveys off Amery Ice Shelf, East Antarctica. Mem. Nat. Inst. Polar Res., 43: 48-61.

Mond, A., 1972. Permian sediments of the Beaver Lake area, Prince Charles Mountains. In Adie, R. J. (Ed.), Antarctic Geology and Geophysics: Oslo (Universitetfolaget), 585-589.

Ravich, M. G., and Fedorov, L. V., 1982. Geologic structure of MacRobertson Land and Princess Elizabeth Land, East Antarctica. In Craddock, C., Loveless, J. K., Vierima, J. L. and Crawford, K. (Eds.), Antarctic Geoscience: Madison (Univ. Wisconsin Press), 499-504.

Sastri, V. V., Raju, A.T.R., Sinha, R. N., and Venkatachala, B. S., 1974. Evolution of the Mesozoic sedimentary basins on the east coast of India. APEA J., 14:29-41.

Shelestov, F. A., and Alyavdin, S. V., 1987. The structure of the western margins of the Prydz Bay sedimentary basin derived from data from multiple geophysical investigations (in Russian). In Geological-Geophysical Research in Antarctica-Collection of Scientific Works: Leningrad (Ministry of Geology, USSR), 143-151.

Sheraton, J. W., 1983. Geochemistry of mafic igneous rocks of the northern Prince Charles Mountains, Antarctica. J. Geol. Soc. Aust., 30:295-304.

Smith, A. G., and Hallam, A., 1970. The fit of the southern continents. Nature, 225:139-144.

Stagg, H.M.J., 1985. The structure and origin of Prydz Bay and MacRobertson Shelf, East Antarctica. Tectonophysics, 114:315-340.

Tingey, R. J., 1982. The geologic evolution of the Prince Charles Mountains-an Antarctic Archean cratonic block. In Craddock, C. (Ed.), Antarctic Geoscience: Madison (Univ. Wisconsin Press), 455-464.

Tingey, R. J., 1985. Uplift in Antarctica. Z. Geomorphol. N. F. Bd., 54: 85-99.

Truswell, E. M., 1982. Palynology of seafloor samples collected by the 1911-14 Australian Antarctic Expedition: implications for the geology of coastal East Antarctica. J. Geol. Soc. Aust., 29:343-356.

Vorren, T. O., Lebesbye, E., Andreassen, K., and Larsen, K. B., 1989. Glacigenic sediments on a passive continental margin as exemplified by the Barents Sea. Mar. Geol., 85:251-272.

Wellman, P., and Tingey, R. J., 1981. Glaciation, erosion, and uplift over part of East Antarctica. Nature, 291:142-144.
Wise, S. W., and Leg 120 Shipboard Party, 1989. Geologic and tectonic evolution of the Kerguelen Plateau as revealed by ODP leg 119 drilling. Proc. 28th Inter. Geological Congress, 28:3-371. (Abstract)

Date of initial receipt: 1 September 1989

Date of acceptance: 24 May 1990

Ms 119B-181

\section{APPENDIX}

Details of Data Processing and Data Availabilty for ODP Line 119

ODP line 119 comprises parts of four single-channel seismic-reflection lines (i.e., lines 5, 6, 7, and 8 from Leg 119) that were individually processed and then merged together into one long transect. The approximate crossing points of individual lines, based on final navigation and/ or similarity of seismic data, were used to merge the lines. In some cases, individual lines did not cross (Table 1), in which case similarities in water depths and subsurface geology were used to determine the merge points. The basic data processing sequence for ODP line 119 is listed below:

\section{Processing Sequence}

1. Resample from $1 \mathrm{~ms}$ to $4 \mathrm{~ms}$

2. Bandpass filter:

Zero-phase, finite-impulse response

Frequency range passed: $40-70 \mathrm{~Hz}$

Hanning taper: start of taper at low end, $30 \mathrm{~Hz}$

end of taper at high end, $90 \mathrm{~Hz}$

Operator length: 101 points applied in time domain

3. Correct for deep water delay

4. Zero bad traces

5. Replace bad traces with average of adjacent traces

6. Automatic gain control: Length: $200 \mathrm{~ms}$

7. Merge lines

8. Plot transect:

Horizontal scale: 118 traces per in.

Vertical scale: 3.3 in. per s

Clip: 2-trace widths

Bias: -0.6 trace widths

Scalar gain: 0.8

Numerous small timing errors were encountered in the field data. Tests were performed with residual static routines to correct these errors. Because the timing errors are larger than the dominant period of the data, residual statics, could not be used even when applied iteratively. The traces with timing errors were zeroed and replaced by the average of adjacent traces.

The dominant frequency range of the instrumental and ambient noise and of the reflected signal was determined by narrow bandpass filter panels. A representative portion of the data was filtered at $5-\mathrm{Hz}$ increments (i.e., $0-5 \mathrm{~Hz}, 5-10 \mathrm{~Hz}, 10-15 \mathrm{~Hz}$, etc.) from 0 to $45 \mathrm{~Hz}$. From 45 to $110 \mathrm{~Hz}$, the test data were filtered at $10-\mathrm{Hz}$ increments. Streamer and ambient noise is dominant from $5-45 \mathrm{~Hz}$ based on these tests. The signal has a bandwidth of $25-70 \mathrm{~Hz}$. Although the $40-\mathrm{Hz}$ low cut for the final filter does not include some of the signal's spectrum, this frequency was optimal in attenuating the noise also present at $25-40 \mathrm{~Hz}$. A high cut of $70 \mathrm{~Hz}$ for the final filter was determined by the high end of the seismic bandwidth.

The seismic data on line ODP-119 have not been deconvolved. Several deconvolution techniques (e.g., spiking, predictive, and minimum entropy) were tested, but none effectively removed the prominent reverberations emanating at/near the seafloor without significantly degrading the deeper data. Predictive deconvolution with short gap lengths (2-4 samples) and spiking deconvolution eliminated the reverberations to varying degrees, but also obscured important deeper events. Minimum entropy deconvolution (wavelet processing) was tested, with no significant effect on the reverberation problem.

Near-seafloor geology appears to strongly control the sub-surface seismic-reflection character in Prydz Bay. One example along line ODP119 (Fig. 18) shows an abrupt change from coherent reflections in the upper $100 \mathrm{~ms}$ of the seafloor (south side) to chaotic reflections (north side). The abrupt acoustic change is not caused by variations in the field 
Table 1. Latitude and longitude for selected waypoints and all drill sites along line ODP-119.

\begin{tabular}{|c|c|c|c|c|c|}
\hline ODP line & Shotpoint & $\begin{array}{c}\text { Time } \\
\text { (JD/Hour) }\end{array}$ & $\begin{array}{l}\text { Latitude } \\
\quad\left({ }^{\circ} \mathrm{S}\right)\end{array}$ & $\begin{array}{l}\text { Longitude } \\
\quad\left({ }^{\circ} \mathrm{E}\right)\end{array}$ & Remarks $^{\mathrm{a}}$ \\
\hline 5 & 316 & $23 / 0832$ & 68.48640 & 76.39058 & Initial point \\
\hline 5 & 400 & $23 / 0845$ & 68.50711 & 76.42678 & Waypoint \\
\hline 5 & 1000 & $23 / 1017$ & 68.65486 & 76.67401 & Waypoint \\
\hline 5 & 1400 & $23 / 1117$ & 68.74907 & 76.84121 & Waypoint \\
\hline 5 & 1487 & $23 / 1130$ & 68.76822 & 76.87348 & $\begin{array}{l}\text { Final point } \\
\qquad(\sim 2.5 \mathrm{nmi} \text { gap })\end{array}$ \\
\hline 6 & 31588 & $27 / 1517$ & 68.47288 & 76.49025 & Initial point \\
\hline 6 & 31600 & $27 / 1519$ & 68.46916 & 76.48599 & Waypoint \\
\hline 6 & 31800 & $27 / 1552$ & 68.40056 & 76.41219 & $\begin{array}{l}\text { Final point } \\
\qquad(\sim 0.5 \mathrm{nmi} \text { gap })\end{array}$ \\
\hline 7 & 65 & $29 / 0813$ & 68.39546 & 76.39546 & Initial point \\
\hline 7 & 100 & $29 / 0819$ & 68.38869 & 76.38118 & Waypoint \\
\hline 7 & 1000 & $29 / 1049$ & 68.17669 & 76.10565 & Waypoint \\
\hline 7 & 2000 & $29 / 1337$ & 67.94094 & 75.84256 & Waypoint \\
\hline 7 & 3000 & $29 / 1626$ & 67.70822 & 75.60800 & Waypoint \\
\hline 7 & 3700 & $29 / 1822$ & 67.53010 & 75.36528 & Waypoint \\
\hline 7 & 3792 & $29 / 1838$ & 67.50864 & 75.33352 & $\begin{array}{l}\text { Final point } \\
\qquad(\sim 0.7 \mathrm{nmi} \text { overlap) }\end{array}$ \\
\hline 8 & 10 & $33 / 0346$ & 67.51904 & 75.35157 & Initial point \\
\hline 8 & 200 & $33 / 0417$ & 67.46035 & 75.28100 & Waypoint \\
\hline 8 & 1000 & $33 / 0617$ & 67.24599 & 75.06542 & Waypoint \\
\hline 8 & 2000 & $33 / 0847$ & 66.97699 & 74.76882 & Waypoint \\
\hline \multirow[t]{6}{*}{8} & 2485 & $33 / 1000$ & 66.84994 & 74.59720 & Final point \\
\hline & & & 67.27617 & 75.08183 & Site 739 \\
\hline & & & 68.68700 & 76.72083 & Site 740 \\
\hline & & & 68.38600 & 76.38367 & Site 741 \\
\hline & & & 67.54967 & 75.40450 & Site 742 \\
\hline & & & 66.91650 & 74.69033 & Site 743 \\
\hline
\end{tabular}

\footnotetext{
a Initial and final points define those parts of ODP lines 5 through 8 (Barron, Larsen, et al., 1989) used to compile line ODP-119 (Fig. 2, back pocket). Latitude and longitudes for waypoints and drill sites are from navigation data listed in Barron, Larsen, et al. (1989). The individual line segments (i.e., ODP lines 5 through 8 ) do not always overlap and data gaps of up to 2.5 nautical miles (nmi) exist in line ODP-119. The drill sites are close to, but not directly on, the line segments used to compile line ODP-119 (i.e., the beacon for each drill site was dropped along other line segments (p. 86, Barron, Larson, et al., 1989)).
}

recording or processing parameters, because the parameters do not change suddenly at this point. Power spectra of the direct arrival signal (air gun to streamer) are the same on both sides of the seafloor change (Fig. 18); however, the power spectrum of the reflected data at the seafloor is sig nificantly different. The power spectrum of the data to the south is similar to that of the direct arrival, yet the power spectrum to the north is much broader, with significant reflected energy below $25 \mathrm{~Hz}$.

The power-spectrum tests indicate that an abrupt change occurs in the near seafloor geology and not in the airgun-source signature. Possible explanations for the chaotic character to the north include glacial scouring of the seafloor, gas or gas hydrates, or discontinuous layering of hard and soft sediment due to glacial loading and unloading (e.g., such as observed in downhole compaction measurements at Sites 739 and 742 (Solheim et al., chapter 9, this volume)).

Copies of the digital seismic and navigation data for the composite processed line ODP-119 (Fig. 2, back pocket) and for individual unprocessed seismic-lines from Leg 119 can be obtained from Ms. Kathe Lighty, Data Librarian, Ocean Drilling Program, Texas A\&M University, 1000 Discovery Drive, College Station, Texas 77845-9547, U.S.A. Copies of paper records for line ODP-119 are available from Mr. Carl Brenner, Ocean Drilling Data Contractor, Lamont-Doherty Geological Observatory, Palisades, NY 10964, U.S.A. BMR (1989) provides information regarding the purchase of digital tapes and paper copies of line PB-21 and other Prydz Bay seismic lines. 


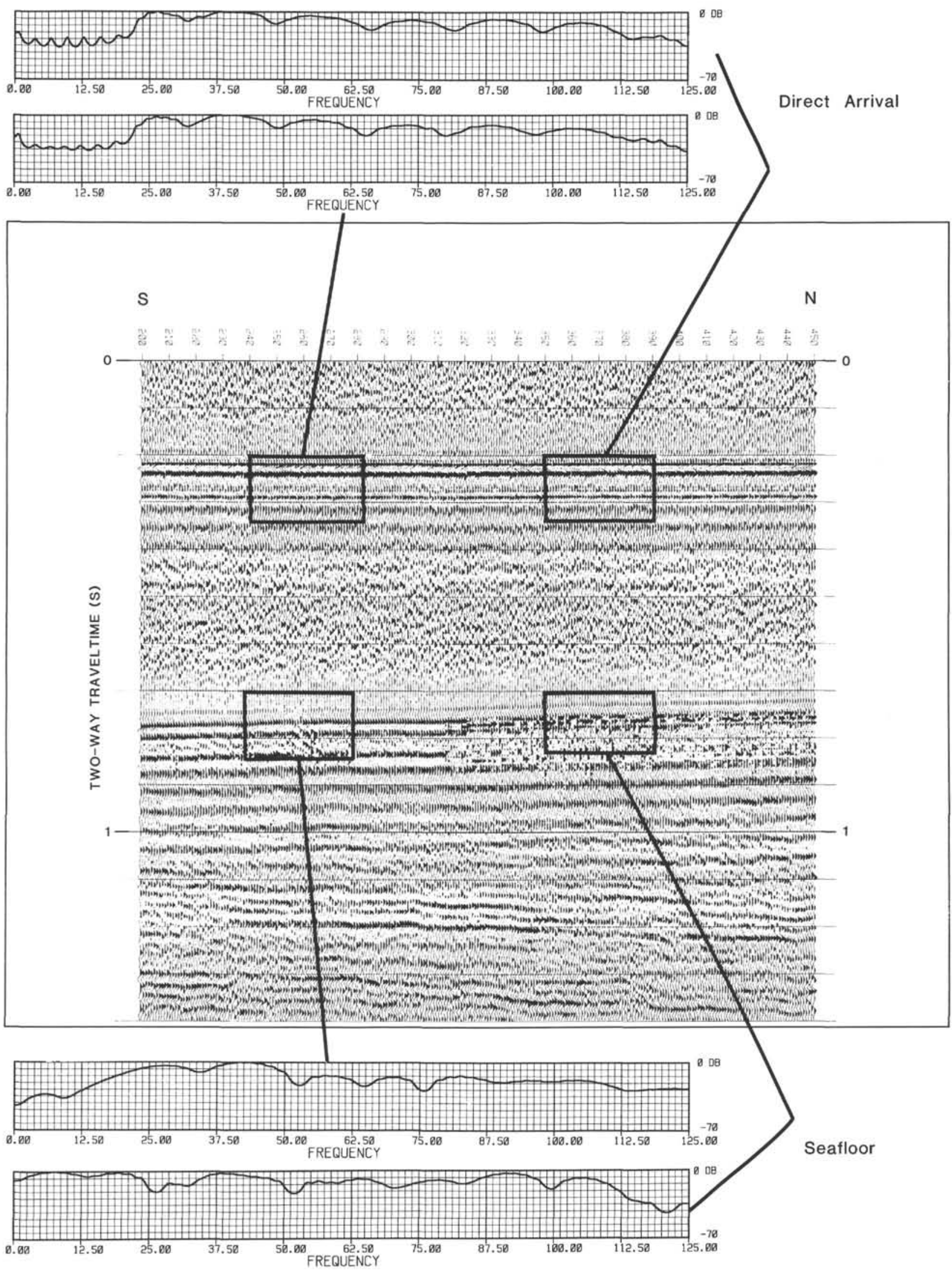

Figure 18. Seismic data and power spectra for part of line ODP-119 near Site 741. The abrupt change in acoustic character of near-seafloor reflections is due to geologic variations (e.g., glacial scour, glacial-interglacial layering, gas or gas hydrates) because power spectra of the seafloor differ, but spectra of the direct arrival are similar, across the discontinuity. See Figure 8 for location. 